\title{
Development of coral-sponge-microbialite reefs in a coated grain-dominated carbonate ramp (Upper Jurassic, eastern Sardinia, Italy)
}

\author{
Mattia Nembrini ${ }^{1}\left[\right.$ [ Giovanna Della Porta ${ }^{1}\left[\right.$ [ Fabrizio Berra ${ }^{1}[\mathbb{D}$
}

Received: 16 July 2020 / Accepted: 10 November 2020 / Published online: 24 December 2020

(c) The Author(s) 2020

\begin{abstract}
The Late Jurassic is a peak time of diversification of reefs with corals, stromatoporoids, calcareous and siliceous sponges, and microbialites during the Phanerozoic. This study focuses on the Callovian-Kimmeridgian carbonate succession of eastern Sardinia, deposited at tropical latitudes on the European passive margin that recorded from the late Oxfordian the evolution from a coated grain-dominated to a reef-bearing carbonate ramp. The coated grain-dominated carbonate ramp (phase 1; Callovian-middle Oxfordian) includes inner ramp ooidal shoals and peloidal packstone in the middle-to-outer ramp. The overlying reef-bearing ramp (phase 2; late Oxfordian-late Kimmeridgian) is characterized by three types (1-3) of bioconstructions. The distribution of these build-ups along the middle-to-outer ramp depositional profile reflects bathymetric parameters, related to the interplay of water energy and light penetration. Type 1 build-ups developed in the proximal middle ramp and consist of $45 \mathrm{~m}$ thick, $100 \mathrm{~m}$ wide, coral-stromatoporoid boundstone associated with coral-stromatoporoid rudstone-grainstone. Type 2 build-ups, colonizing deeper environments in the middle ramp, are lens-shaped coral-calcareous sponge-diceratid boundstone including stromatoporoids and chaetetid sponges, 1-2 m thick and 3-4 m wide, associated with bioclastic packstone-grainstone. Type 3 lens-shaped calcareous and siliceous sponge-coral-microbialite boundstone build-ups ( $1 \mathrm{~m}$ thick and a few metres wide) formed in lower energy, distal middle-to-outer ramp settings. The evolution of the eastern Sardinian carbonate ramp reflects the Oxfordian-Kimmeridgian spread of the coral-sponge-microbialite reefs along the Tethyan European passive margin.
\end{abstract}

Keywords Carbonate ramp $\cdot$ Reefs $\cdot$ Corals $\cdot$ Stromatoporoids $\cdot$ Sponges $\cdot$ Upper Jurassic $\cdot$ Sardinia

\section{Introduction}

The Late Jurassic represents a time of exceptional abundance of coral, stromatoporoid, calcareous, and siliceous sponge and microbialite reefs in the Phanerozoic (Leinfelder et al. 2002; Cecca et al. 2005; Kiessling 2009; Martin-Garin et al. 2012). This significant phase of reef development is coeval with major tectonic plate reorganizations, marked by the breakup of Pangea, which started in the Late Triassic and led to the opening of the Central Atlantic and Alpine Tethys, followed by the North and South Atlantic, Indian Ocean and

Mattia Nembrini

mattia.nembrini@unimi.it

1 Dipartimento di Scienze Della Terra "A. Desio”, Università degli Studi di Milano, Via Mangiagalli 34, 20133 Milan, Italy the Bay of Biscay (Stampfli and Borel 2002; Golonka 2004, 2007; Beutel et al. 2005; Masini et al. 2013; Frizon de Lamotte et al. 2015; Leleu et al. 2016; Müller et al. 2016). In this period of global tectonic reorganization, major climatic changes and sea-level fluctuations (Dromart et al. 2003; Jenkyns et al. 2011; Haq 2018), and reef-building biota diversified and gave rise to a great variety of reef types, dominated by corals, stromatoporoids, various calcareous and siliceous sponges, bivalves, and microbialites or a mixture of them (Leinfelder et al. 2002). Starting from the middle Oxfordian, when a eustatic sea-level rise (Cecca et al. 2005), likely driven by climate warming (Dromart et al. 2003; Dera et al. 2011), is documented, reefs consisted of metazoan (mostly corals and stromatoporoids) and microbialites. The record of the global distribution of Upper Jurassic reefs with corals, calcareous, and siliceous sponges and microbialites is well documented in attached platforms of the northern margin of the Alpine Tethys (Spain, Olóriz et al. 2003a; Reolid et al. 
2005; Bádenas and Aurell 2010; San Miguel et al. 2017; Swiss Jura, Dupraz and Strasser 2002; Samankassou et al. 2003; Strasser and Védrine 2009; French Jura, Lathuilière et al. 2005; Olivier et al. 2011; Northwestern France, Olivier et al. 2003, 2008; Carcel et al. 2010; Germany, Olivier et al. 2004), in the intra-Tethys isolated platforms (Plassen, Northern Calcareous Alps, Schlagintweit and Gawlick 2007, 2008; Adriatic platform, Turnšek et al. 1981; Tišljar and Velić 1991; Dragičević and Velić 2002; Velić et al. 2002; Vlahović et al. 2002; Apennine platform, Rusciadelli et al. 2011; Apulian platform, Russo and Morsilli 2007; Santantonio et al. 2013), in the southern Tethys epeiric platform of Saudi Arabia (Al-Husseini 1997; Hughes 2004; El-Sorogy et al. 2018), and in the Atlantic platforms (Portugal, Leinfelder 1993a; Nose and Leinfelder 1997; Nova Scotia, Jansa et al. 1988; Pratt and Jansa 1988).

Laterally extensive well-exposed outcrops of carbonate depositional systems with a wide variety of facies and Oxfordian-Kimmeridgian and Tithonian coral-stromatoporoid-sponge-microbialite reefs are present in the Middle Jurassic-to-Berriasian (Lower Cretaceous) stratigraphic succession of eastern Sardinia (Fig. 1). Previous studies focused on the stratigraphic reconstruction of the sedimentary succession (Jadoul et al. 2009, 2010; Lanfranchi et al. 2011; Casellato et al. 2012; Jadoul 2018; Muttoni et al. 2018) and on the characterization of Tithonian reefs (Ricci et al. 2018). This study focuses on the Callovian-Kimmeridgian southern portion (Fig. 1) of the carbonate ramp system (Dorgali, Mt. Tului and Baunei formations, sensu Jadoul et al. 2009, 2010) that recorded a transition from a carbonate succession characterized by coated grains, echinoderms, and peloids to a carbonate factory dominated by reefs with variable proportions of corals, stromatoporoids, calcareous and siliceous sponges, and microbialites. Thanks to the intermediate palaeogeographic position between the northern Tethys and the intra-Tethys platforms in the south-western portion of the northern margin of the Alpine Tethys (Fig. 2; Dercourt et al. 2000) and affinities with both provinces, the study of eastern Sardinia carbonate system provides insights on the factors influencing carbonate lithofacies character, reef composition, and architecture during the Late Jurassic.

\section{Geological setting}

The up to $650 \mathrm{~m}$-thick Middle Jurassic-Lower Cretaceous carbonate succession of eastern Sardinia (Orosei Gulf; Fig. 1a) accumulated on the southern European passive margin of the Alpine Tethys (Fourcade et al. 1993; Costamagna and Barca 2004; Costamagna 2016). During the Late Jurassic, Sardinia was located at tropical palaeolatitude (Fig. 2) along the northern coast of the Alpine Tethys (Dercourt et al. 2000; Muttoni et al. 2018) and was characterized by an SW-NE oriented (N-S in present-day coordinates) emerged ridge of Hercynian metamorphic basement and Permian volcanic rocks (Vardabasso 1959; Dieni and Massari 1985) separating the ocean-facing eastern Sardinia succession from a restricted epicontinental sea to the north west (Cherchi and Schroeder 1985; Cherchi et al. 2010).

The carbonate succession of eastern Sardinia accumulated above a Hercynian basement peneplain, with shallowwater carbonates transitional eastward, northward, and southward to deeper basinal areas (Fig. 1a, b; Jadoul et al. 2009; Casellato et al. 2012). The succession consists of different lithostratigraphic units (Amadesi et al. 1961; Dieni and Massari 1985; revised by Jadoul et al. 2009; Jadoul 2018; Fig. 1c) that represent superimposed carbonate units reflecting different depositional regimes. The carbonate succession started with marine transgressive carbonates covering the Palaeozoic Hercynian basement, Permian volcanic rocks (Fig. 1a) or Bajocian-lower Bathonian discontinuous lenses (up to $50 \mathrm{~m}$ thick) of polygenic fluvial conglomerates, lacustrine and marginal marine shales, and coastal sandstone, labelled as Genna Selole Fm (Fig. 1c; Dieni and Massari 1985; Costamagna et al. 2007; Costamagna 2016). The first marine carbonate deposits are referred to as Dorgali Fm (sensu Jadoul et al. 2009, 2010), which consists of dolomitized cross-laminated ooidal grainstone-to-packstone with detrital quartz associated with oo-crinoidal grainstoneto-packstone of Bathonian-Callovian age. The overlying Mt. Tului Fm, Baunei Fm and S'Adde Limestone record the evolution through time of a carbonate ramp (Fig. 1c; Jadoul et al. 2009, 2010). In its lower part (approximately until middle Oxfordian), this carbonate ramp was characterized by the deposition of ooidal grainstone in the central NW area (Urzulei Supramonte, US in Fig. 1b) interfingering basinward with oo-crinoidal grainstone-packstone (lower Mt. Tului Fm), laterally passing to packstone-wackestone with chert nodules (lower Baunei Fm, Jadoul et al. 2009) in the southern basinal area (Baunei Supramonte, BS in Fig. 1B). The depositional system evolved (probably during late Oxfordian-Kimmeridgian) to a carbonate ramp with coral-stromatoporoid reefs in the central NW area (upper Mt. Tului Fm; Fig. 1b, c) passing distally to peloidal packstone-wackestone in the northern (S'Adde Limestone) and southern (upper Baunei Fm) basinal areas. The top of Mt. Tului Fm is characterized by a major regressive event marked by the subaerial exposure of the proximal area of the carbonate system (Jadoul et al. 2009) and by conglomerates with black pebbles and peritidal facies with fenestrae, tepees, mud-cracks, and stromatolites (Urzulei Fm, Jadoul et al. 2009). The upper part of the succession (approximately lower Tithonian-Berriasian) represents the recovery of the carbonate system after the subaerial exposure, with the development of coral-stromatoporoid reefs with high coral diversity (lower Mt. Bardia Fm, Ricci et al. 2018). The 


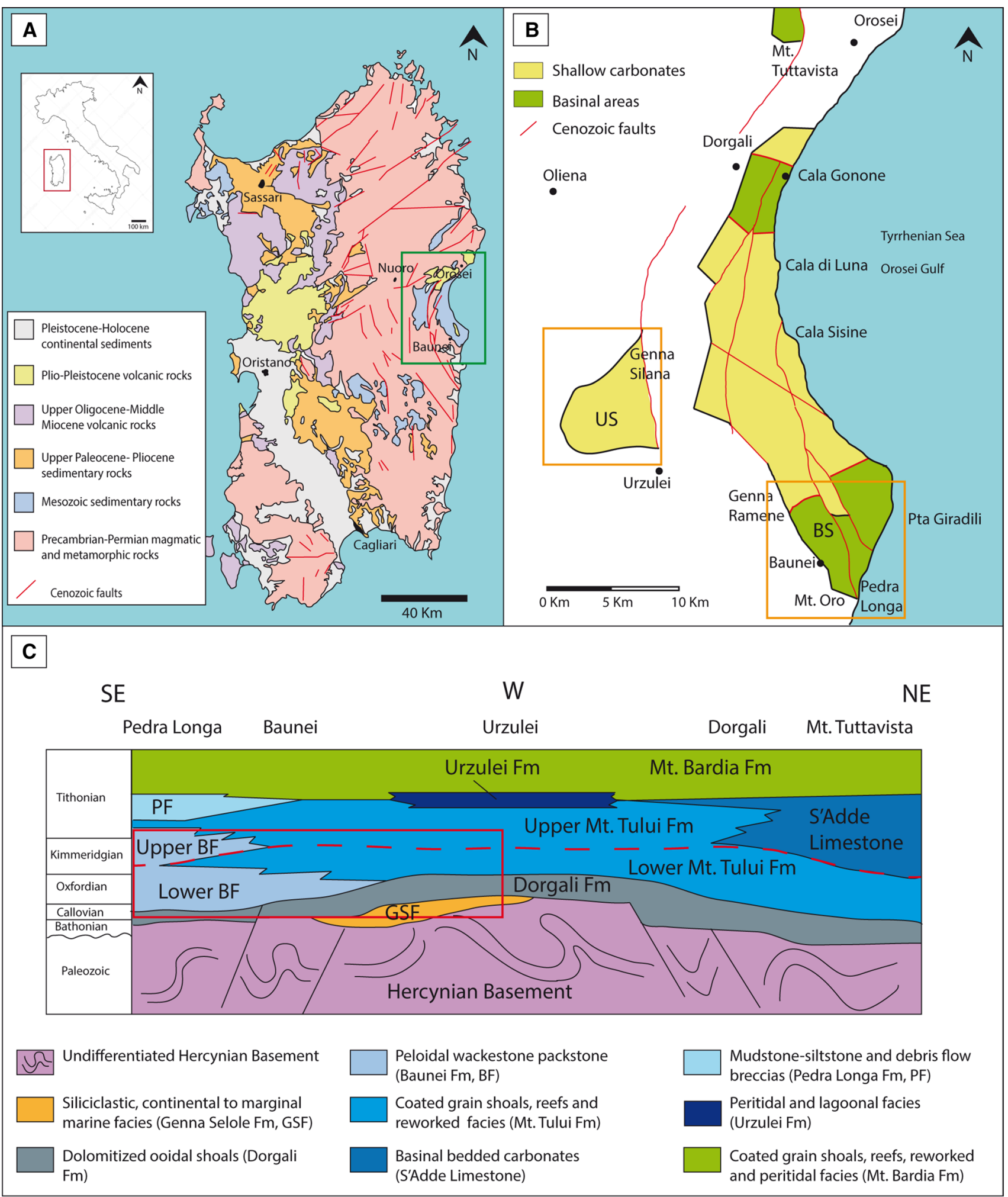

Fig. 1 a Simplified geological map of Sardinia, with the distribution of the Middle Jurassic-to-Berriasian carbonate succession in eastern Sardinia. The study area is marked by a green box (modified after Carmignani et al. 2008). b Distribution of the outcrops of Jurassic shallow water and basinal carbonates in the Orosei Gulf. The investigated areas are marked by the orange squares: Urzulei Supramonte (US) and Baunei Supramonte (BS); modified after Jadoul (2018). c
Stratigraphic scheme of the Middle-to-Upper Jurassic carbonate succession of eastern Sardinia. The red square marks the stratigraphic succession investigated in this study; the red dashed line marks the separation between lower and upper Mt. Tului Fm; redrafted after Jadoul et al. (2009, 2010), Lanfranchi et al. (2011) and Casellato et al. (2012) 


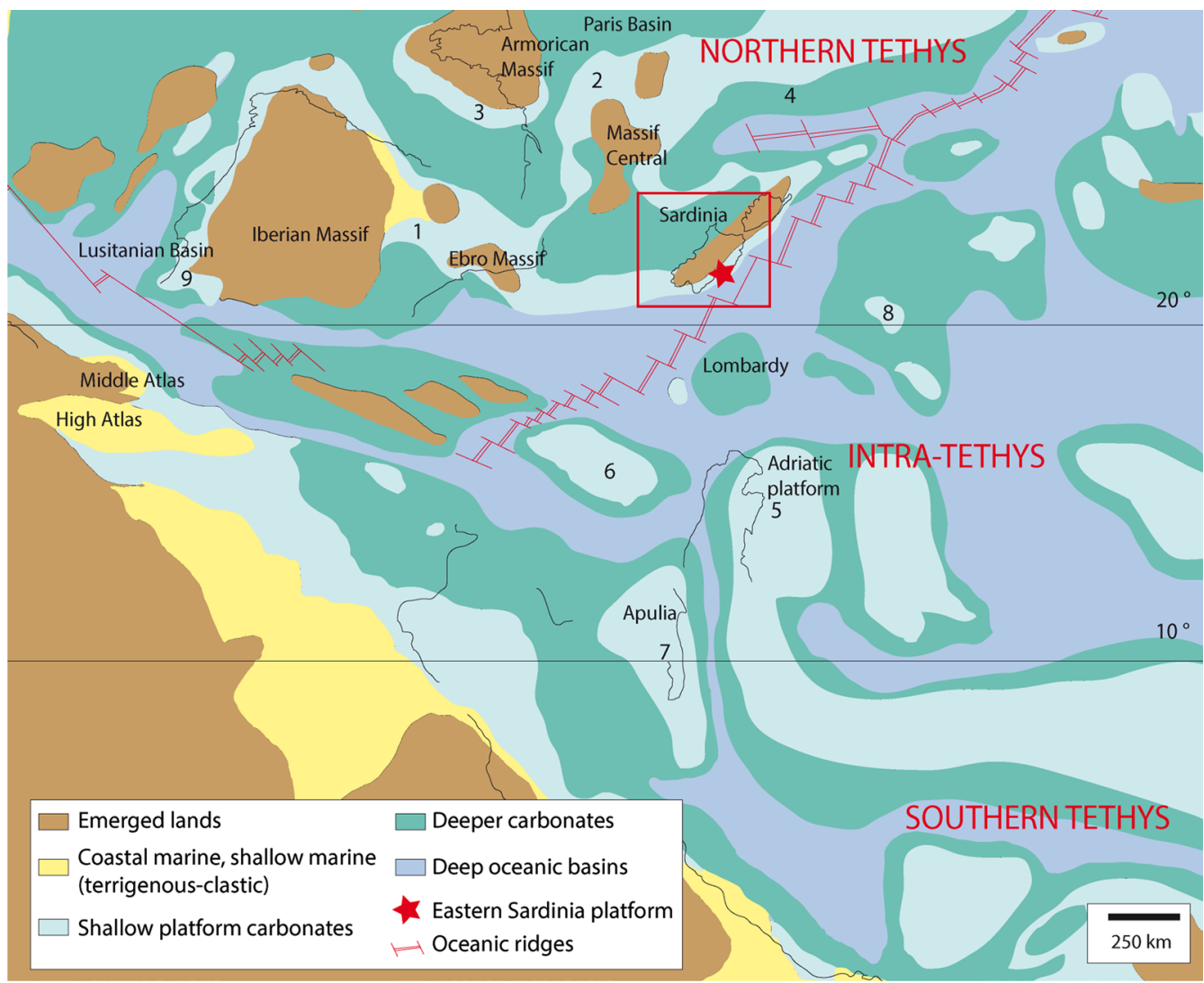

Fig. 2 Palaeogeographic map of Tethys realm during the Kimmeridgian, with the position of Sardinia (red square); modified after Dercourt et al. (2000). The distribution of coeval reefal carbonate systems is marked as: 1 Iberian Basin coral-microbial build-ups and stromatoporoid carpets (Bádenas and Aurell 2010); 2 France Lorraine and Jura carbonate platforms with coral-microbialite reefs (Dupraz and Strasser 2002; Lathuilière et al. 2005; Olivier et al. 2008, 2011); 3 La Rochelle coral-microbialite reefs (Taylor and Palmer 1994; Olivier et al. 2003, 2008); 4 Germany siliceous sponge mounds

transgression is recorded in the southern basin by the deposition of thin-bedded marly limestone (Pedra Longa Fm), followed by prograding clinostratified sigmoidal bioclastic deposits (lower Mt. Bardia Fm, Lanfranchi et al. 2011).

\section{Materials and methods}

This study investigates the Middle-Upper Jurassic (Callovian-Kimmeridgian) carbonate succession, including the upper part of the Dorgali Fm and the Mt. Tului and Baunei formations (sensu Jadoul et al. 2009, 2010) in the southern portion of the Orosei Gulf, in terms of facies character and distribution through 11 stratigraphic logs in the Baunei Supramonte (BS) and Urzulei Supramonte (US) areas (Fig. 1b). The correlation of stratigraphic logs was performed based on stratigraphic key surfaces and facies
(Swabian and Franconian Alb; Olivier et al. 2004); 5 Adriatic platform stromatoporoid, coral, chaetetid reefs (Vlahović et al. 2002); 6 Apennines carbonate platform with coral stromatoporoid reefs (Rusciadelli et al. 2011); 7 Apulian carbonate platform stromatoporoidcoral reef (Santantonio et al. 2013); 8 Northern Calcareous Alps coral-stromatoporoid reefs (Plassen carbonate platform; Schlagintweit and Gawlick 2007, 2008); 9 Portugal carbonate platforms in Atlantic realm with reefs with corals, stromatoporoids, siliceous sponges, and microbialites (Nose and Leinfelder 1997)

changes integrated with previous stratigraphic studies (cf. Jadoul et al. 2009; 2010).

Facies analysis was based on outcrop descriptions and petrographic analysis of about 270 polished slabs and 170 thin sections. The semi-quantitative proportion of skeletal and non-skeletal grains in thin sections was determined based on visual estimates using the comparison charts of percentage of constituents proposed for limestones by Baccelle and Bosellini (1965). For the description of coated grains, the nomenclature by Strasser (1986) was adopted. Strasser (1986) defined 6 ooid types: (1) type 1 ooids are well rounded and display fine micritic concentric laminae and possible sparite replacement, (2) type 2 ooids are irregularly shaped with fine micritic laminae (often evolving into oncoids), (3) type 3 ooids display cortices composed of several fine laminae forming a radial structure; they can appear patchily micritized and evolve into irregularly shaped coated grains, (4) type 4 ooids have 1-4 laminae and display fine 
radial structure, (5) type 5 have one lamina with a coarse radial structure, and (6) type 6 ooids display mixed cortices. Microfacies analysis and nomenclature of sponges are based on Flügel (2004) that defined: calcareous sponges as a nonsystematic term for calcisponges exhibiting calcite spicules or a calcareous skeleton; chaetetids as fossils composed of densely packed, thin calcareous tubes with horizontal partitions; stromatoporoids as fossil sponges (regarded as being related to demosponges or as a separate class of sponges) represented by calcified skeletons of domical to columnar forms, with internal structures parallel and perpendicular to the surface and distinct canal systems (astrorhizae) at the surface; siliceous sponges as an informal term for sponges with a skeleton composed of siliceous spicules, including both demosponges and hexactinellids.

To identify the presence of dolomite and ferroan calcite cement, some of the thin sections were stained with alizarin red and potassium ferricyanide (cf. Dickson 1966). Thin sections were examined under cathodoluminescence microscopy with a luminoscope Cambridge Image Technology Limited (CITL), Cambridge, UK (model MK 5-2 operating system at $10-16 \mathrm{kV}$ with a beam current between 200 and $400 \mu \mathrm{A}$, and vacuum gauge 50-70 millitor).

\section{Results}

\section{Facies types}

Outcrop-based facies investigation and petrographic analysis allowed distinguishing 13 carbonate facies, labelled from F1 to F13 (Table 1), differently distributed within the Callovian to upper Kimmeridgian succession of the Dorgali, Mt. Tului and Baunei formations (sensu Jadoul et al. 2009, 2010).

Facies F1 is a partially dolomitized cross-bedded ooidalcoated grain grainstone-to-packstone, with beds $0.5-1 \mathrm{~m}$ thick and local herringbone cross-lamination (Fig. 3a). It contains partially micritized ooids with radial sparitic laminae (type 3 ), micritic ooids (type 1), and aggregate and coated grains with micrite envelopes (Fig. 3b). Discontinuous beds (1-15 mm thick) of siliceous sponge spicule wackestone may alternate within fining-upward grainstone beds with dominant type 1 micritic ooids (Fig. 3c). Facies F2 is a cross-laminated echinoderm packstone-to-grainstone-rudstone (Fig. 3d) in planar beds up to $1 \mathrm{~m}$ thick, with fining-upward grain-size trends, also partially dolomitized as F1 (Table 1). Facies F3-peloidal packstone is well bedded (0.2-1 $\mathrm{m}$ thick) and includes ooids and echinoderms. Facies F4-peloidal packstone with chert nodules and thinshelled bivalves (Fig. 3e) is characterized by bioturbated thin nodular beds $(5-10 \mathrm{~cm})$ dominated by peloids and finegrained coated grains $(100-200 \mu \mathrm{m})$. Facies F5 is an ooidal grainstone-to-packstone with intraclasts and bioclasts (beds
$0.5-1 \mathrm{~m}$ thick), dominated by type 3 partially micritized radial ooids and type 1 micritic tangential ooids (Fig. 3f, g). Facies F6 (0.2-1 m thick beds) consists of peloidal packstone with reworked intraclasts (mainly clotted peloidal and dense micrite fragments), skeletal fragments, ooids (type 1), oncoids, and coated grains with micrite envelopes. Facies F7 consists of burrowed peloidal packstone to locally wackestone with Lenticulina foraminifer (Fig. 3h) in thin, nodular beds $(5-30 \mathrm{~cm}$ thick). Facies F8 consists of crosslaminated beds ( $0.5-1 \mathrm{~m}$ thick) of bioclastic packstone-tograinstone-rudstone rich in sub-angular-to-rounded intraclasts of clotted peloidal micrite and dense micrite fragments (Fig. 4a, b). Facies F9 is a poorly sorted, massive, coralstromatoporoid rudstone-grainstone with common colonial (thamnasterioids) and solitary corals and stromatoporoids (Fig. 4c, d), with encrustations by clotted peloidal micrite. Facies F9 contains also sub-angular-to-rounded intraclasts of clotted peloidal micrite (Fig. 4e) and dense micrite and peloids. Facies F10 consists of massive coral-stromatoporoid boundstone (Fig. 4f) tens of metres thick (14-45 m) with coral colonies in life position ( $0.05-2 \mathrm{~m}$, mainly phaceloid, cerioid, and thamnasterioid; Fig. 4g, h), associated with stromatoporoids, undetermined calcareous sponges, and encrusted by clotted peloidal micrite, serpulids, and foraminifers (Troglotella incrustans, Fig. 5a, b). Facies F11 is a coral-calcareous sponge-diceratid boundstone whose framework consists of dominant coral colonies and undetermined calcareous sponges in life position (Fig. 5c-e) with sparse stromatoporoids. Coral colonies (mainly phaceloid and cerioid) are often encrusted by solenoporaceans (Fig. 5f), Bacinella irregularis (Fig. 5g), Lithocodium aggregatum (Fig. 5h), and clotted peloidal micrite associated with diceratid bivalves (Fig. 5e). Facies F12 sponge-coral-microbialite boundstone consists of calcareous (Fig. 6a) and siliceous sponges (hexactinellid, Fig. 6b), chaetetids, solitary, and phaceloid corals (Fig. 6c) and solenoporaceans showing coatings by micritic clotted peloidal micrite and Crescentiella morronensis (Fig. 6d). There are boring cavities filled by peloidal packstone (Fig. 6e) that also fills some primary growth framework voids. Facies F13 is a planar bedded (50 $\mathrm{cm}$ to $1 \mathrm{~m}$ thick), poorly sorted skeletal rudstone-topackstone, rarely grainstone, with coated grains and common stromatoporoids (up to $10 \mathrm{~cm}$ in diameter; Fig. $6 \mathrm{f}-\mathrm{h}$ ), peloids, aggregate grains (bound by Bacinella irregularis) and type 1 ooids.

\section{Dolomitized facies}

As displayed in the stratigraphic logs (Fig. 7), facies characterization suffered the widespread presence of replacive dolomitization in the lower part of the succession, close to the Hercynian basement comprising the Dorgali Fm and lower part of Mt. Tului Fm (e.g., the basal $20 \mathrm{~m}$ at Mt. 


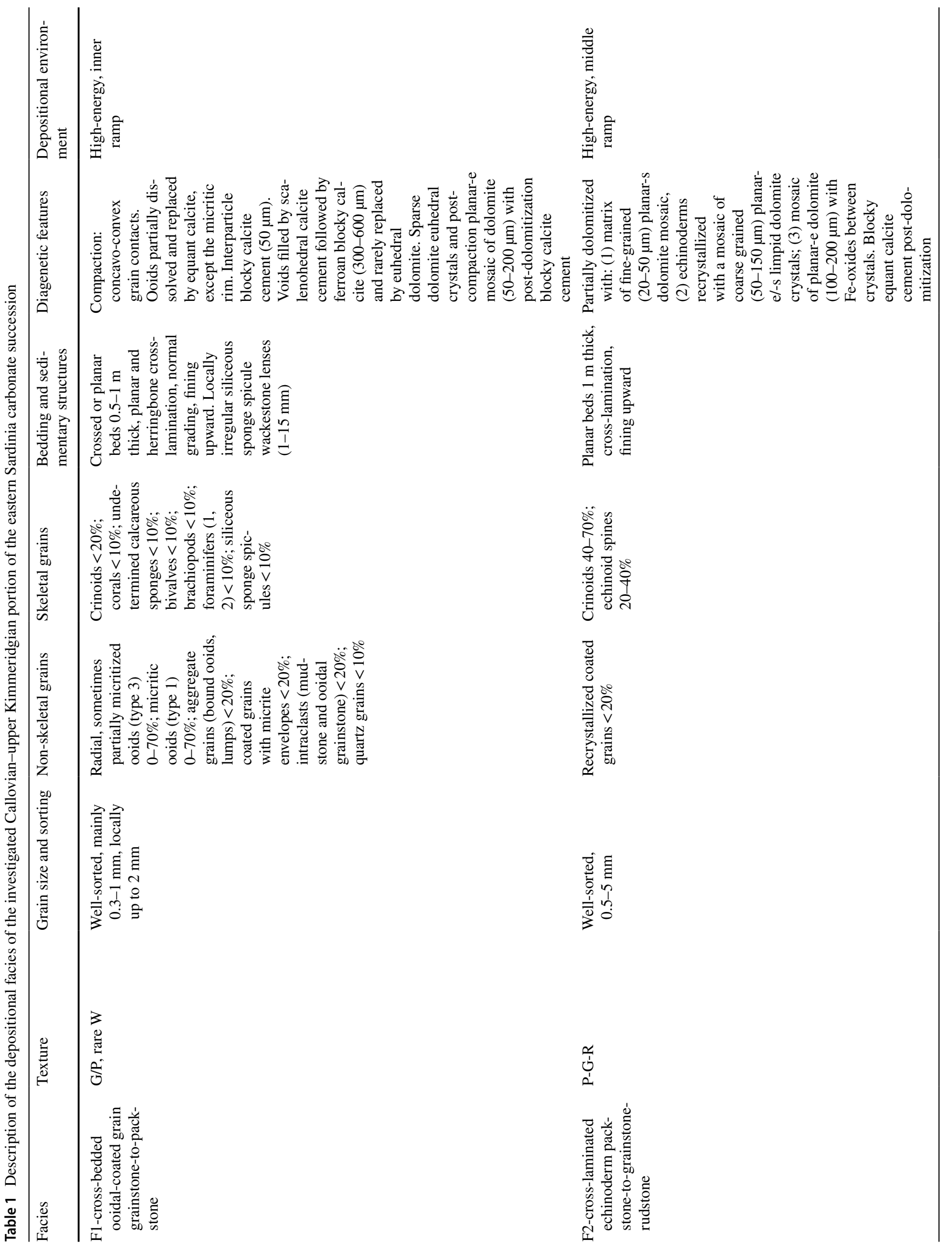









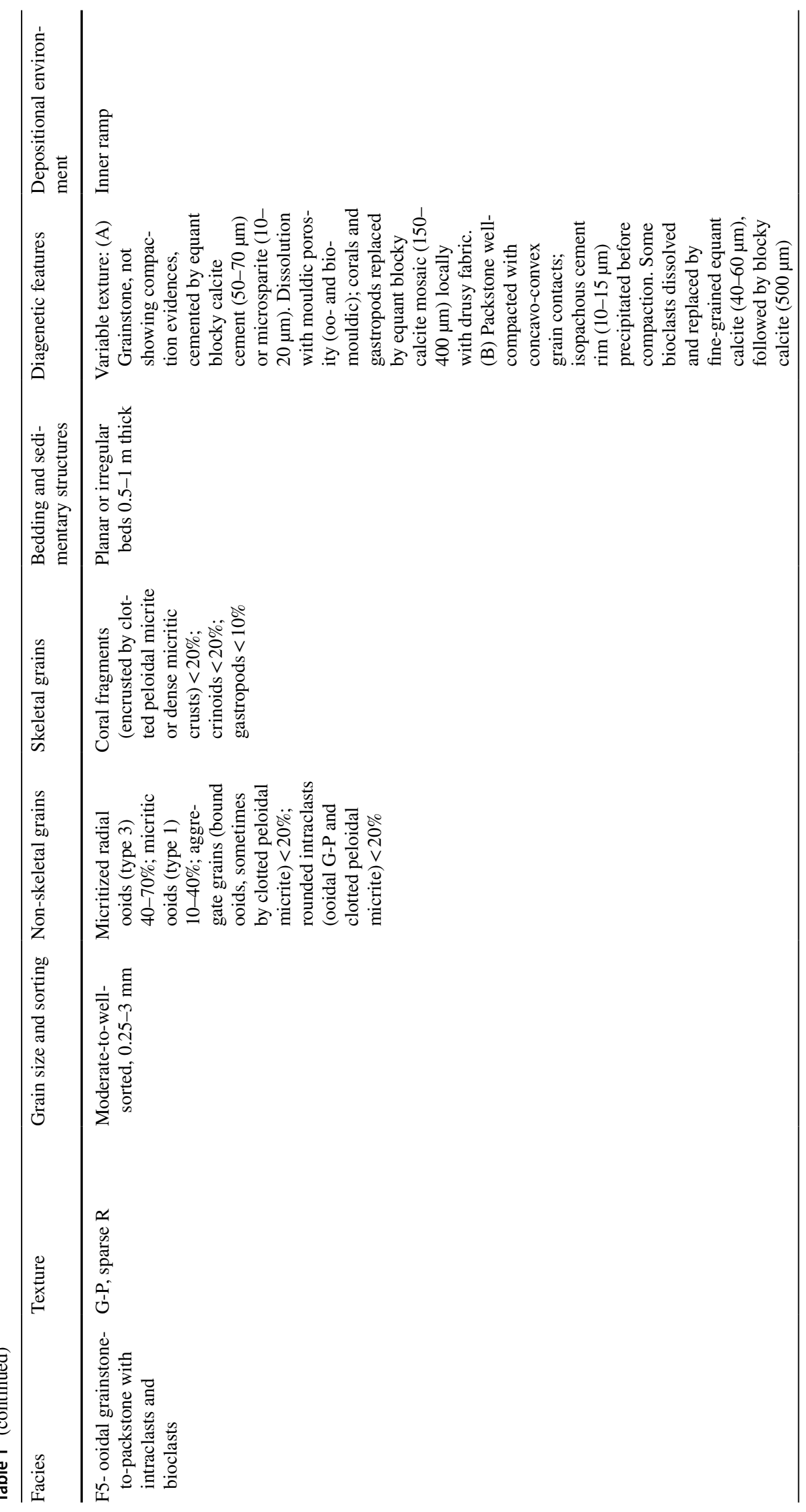




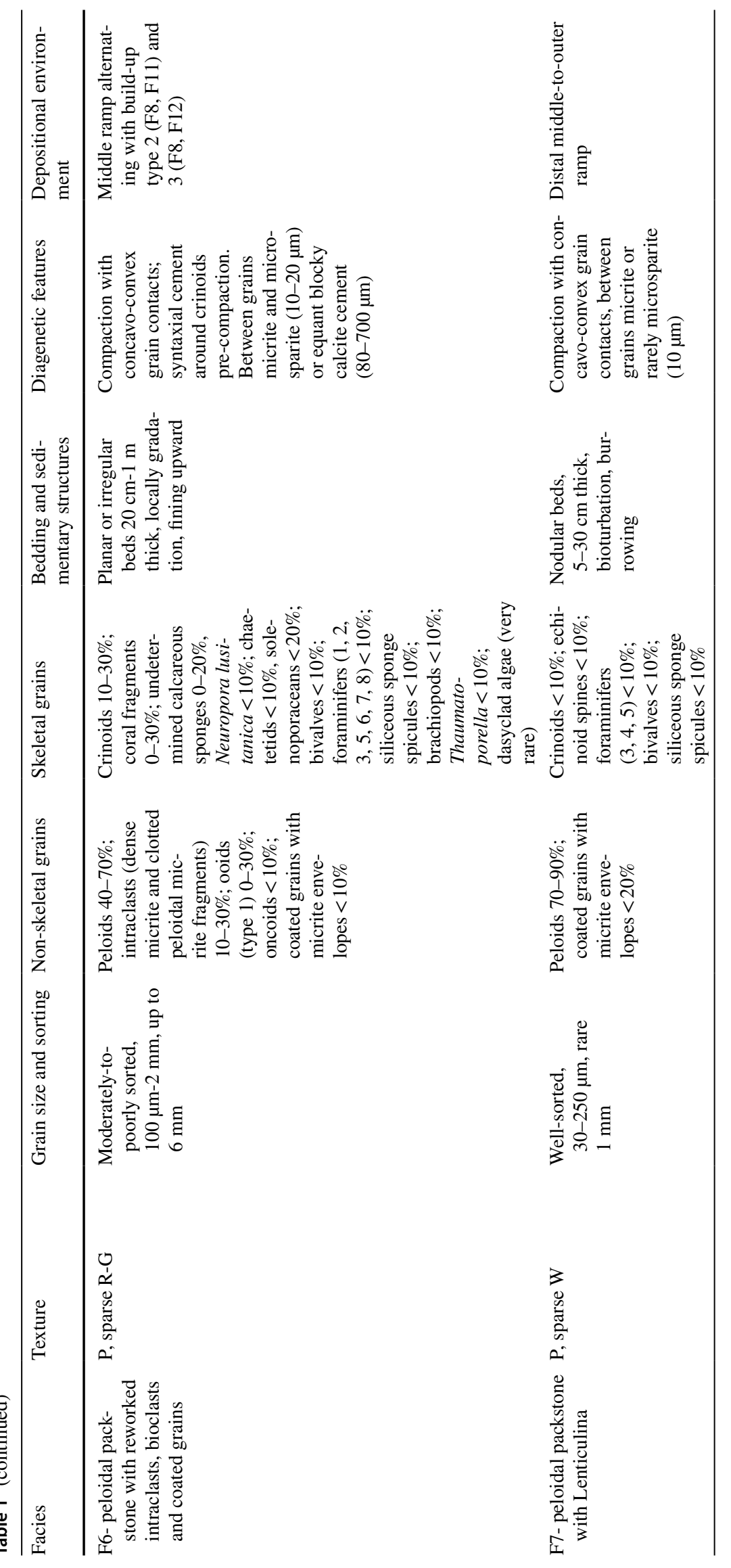




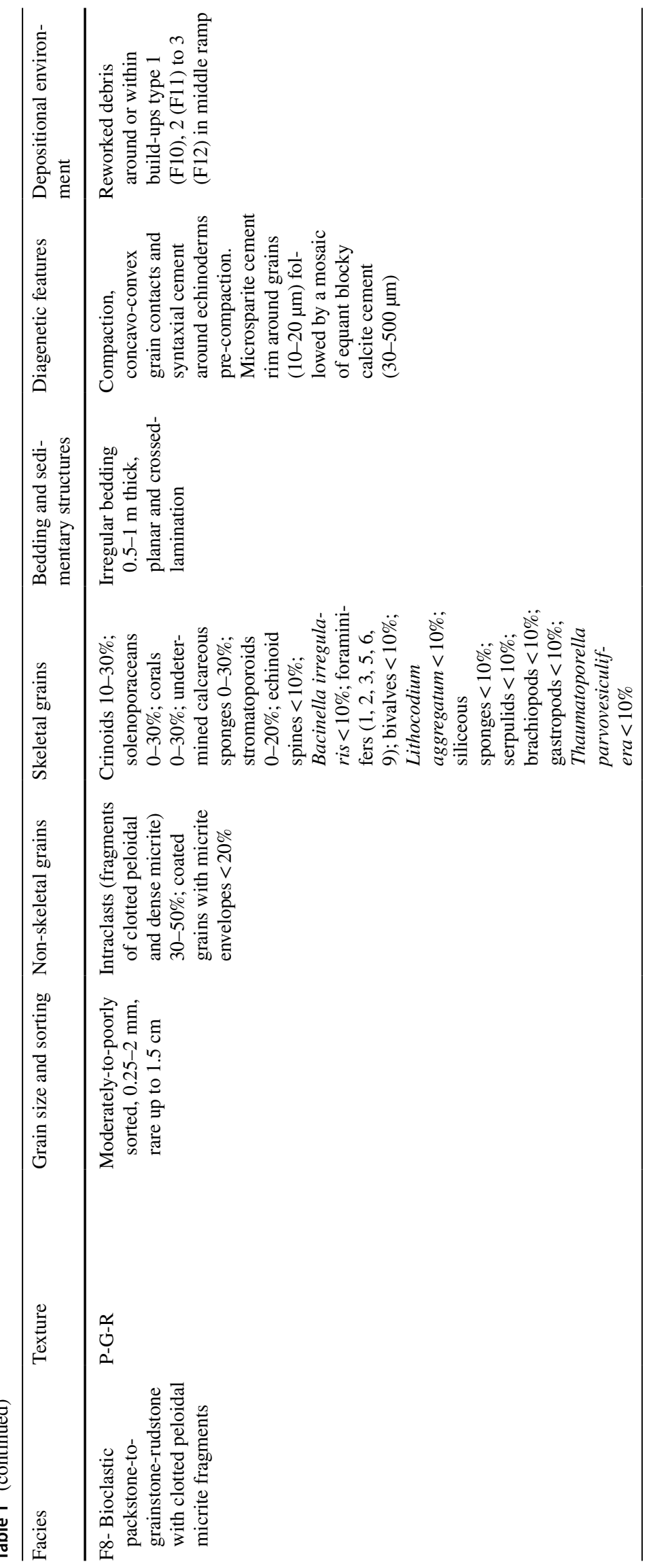




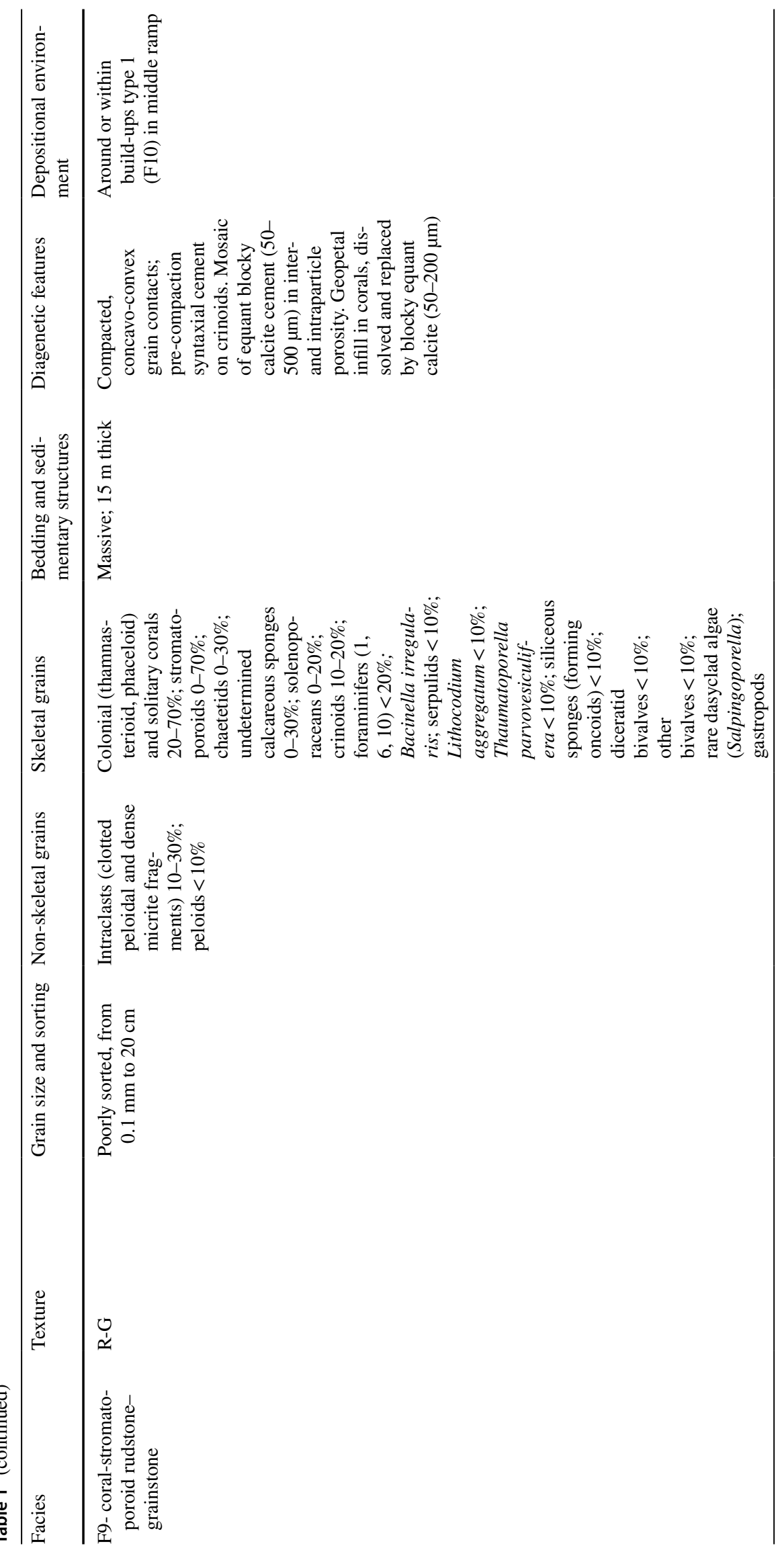




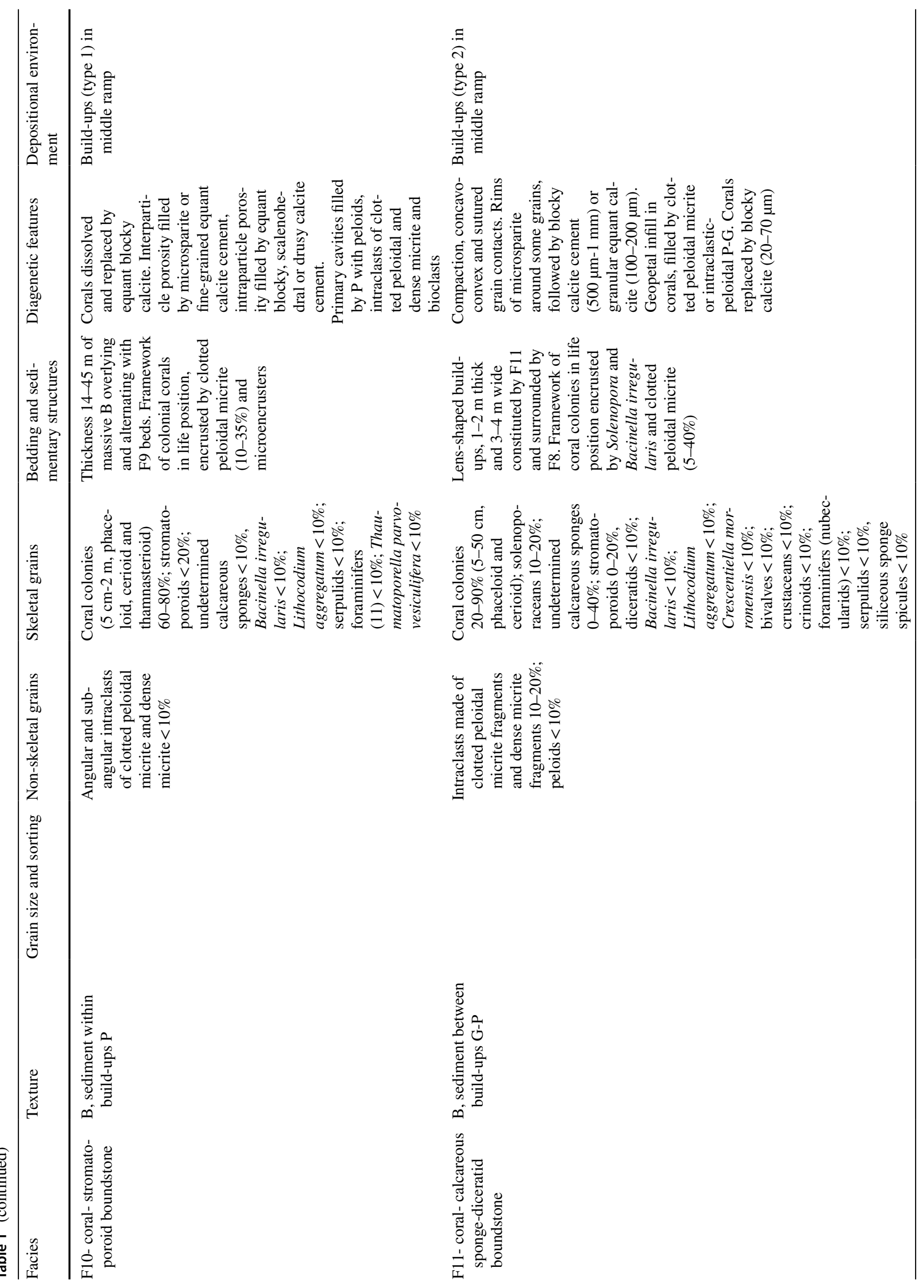




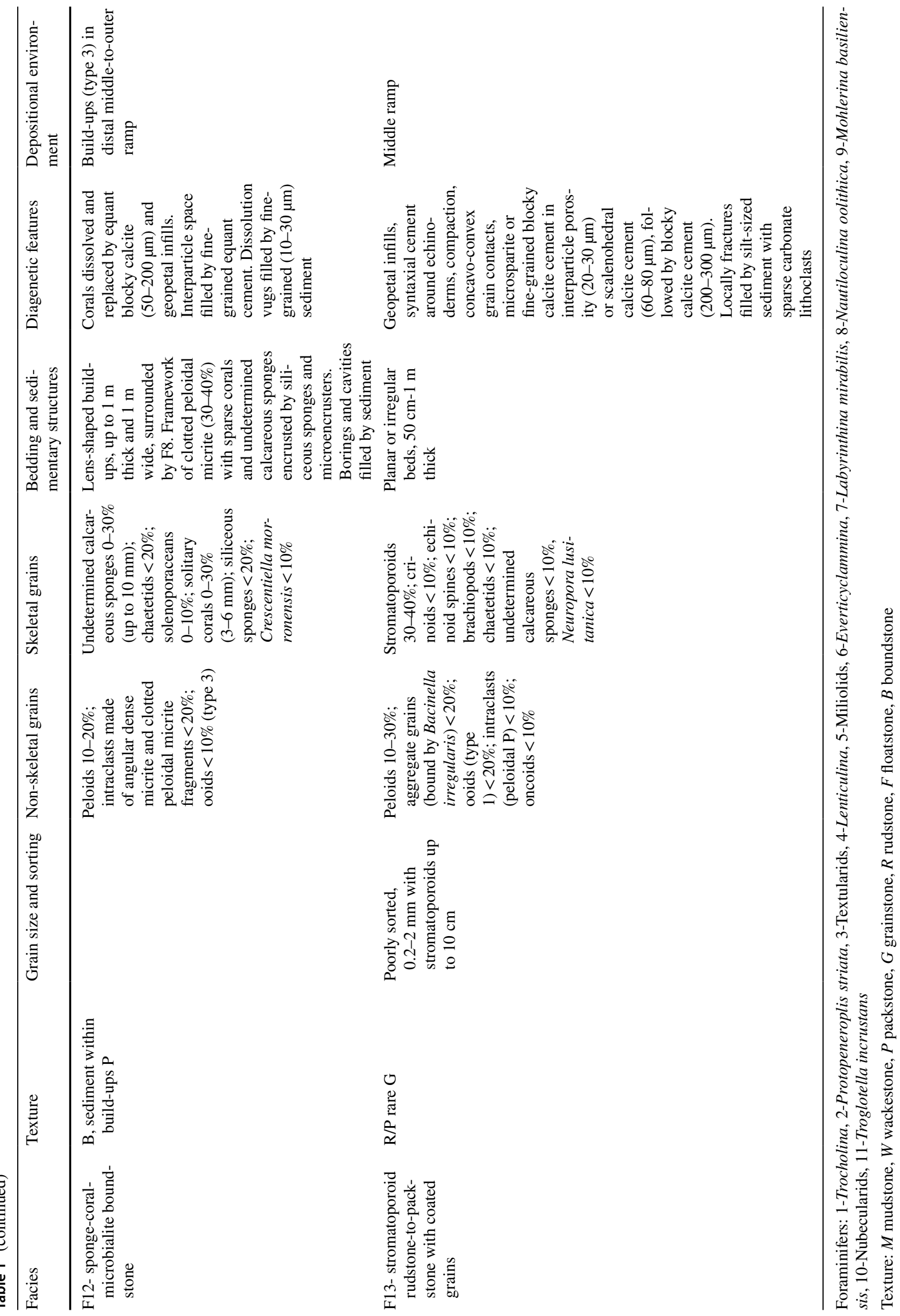



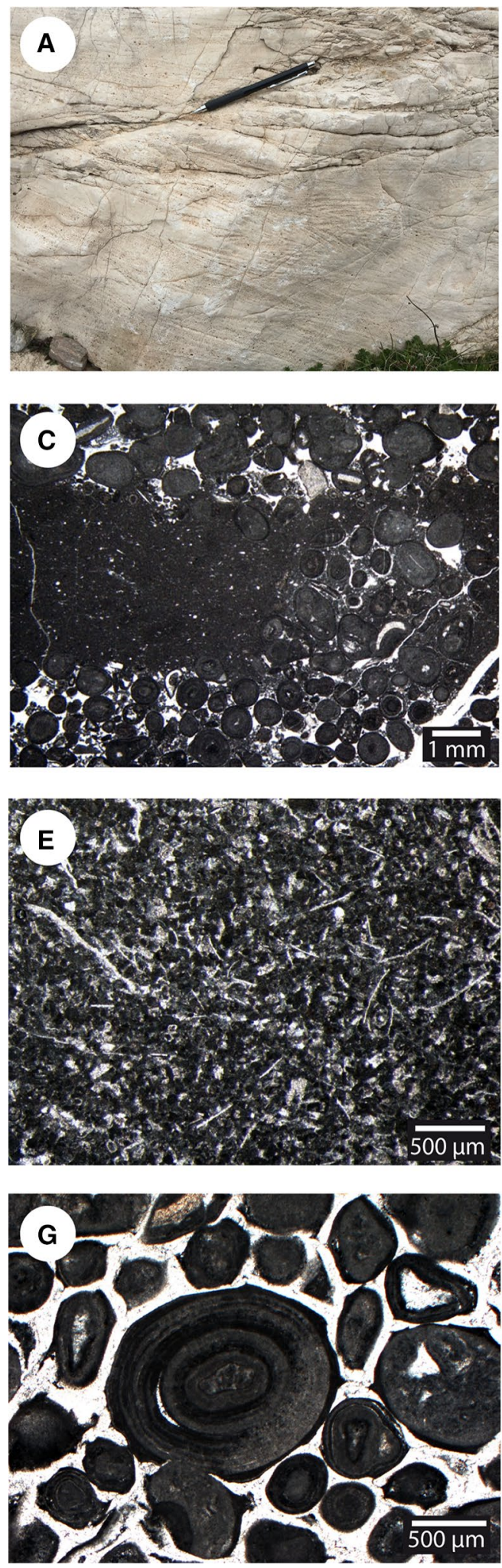

Oro, $40 \mathrm{~m}$ at Genna Scalas, $25 \mathrm{~m}$ at Baunei Supramonte to $150 \mathrm{~m}$ at Genna Silana). Outcrop exposures show stratabounding dolomitization or patchily dolomitized volumes (Fig. 8a). Some portions of the succession are only partially
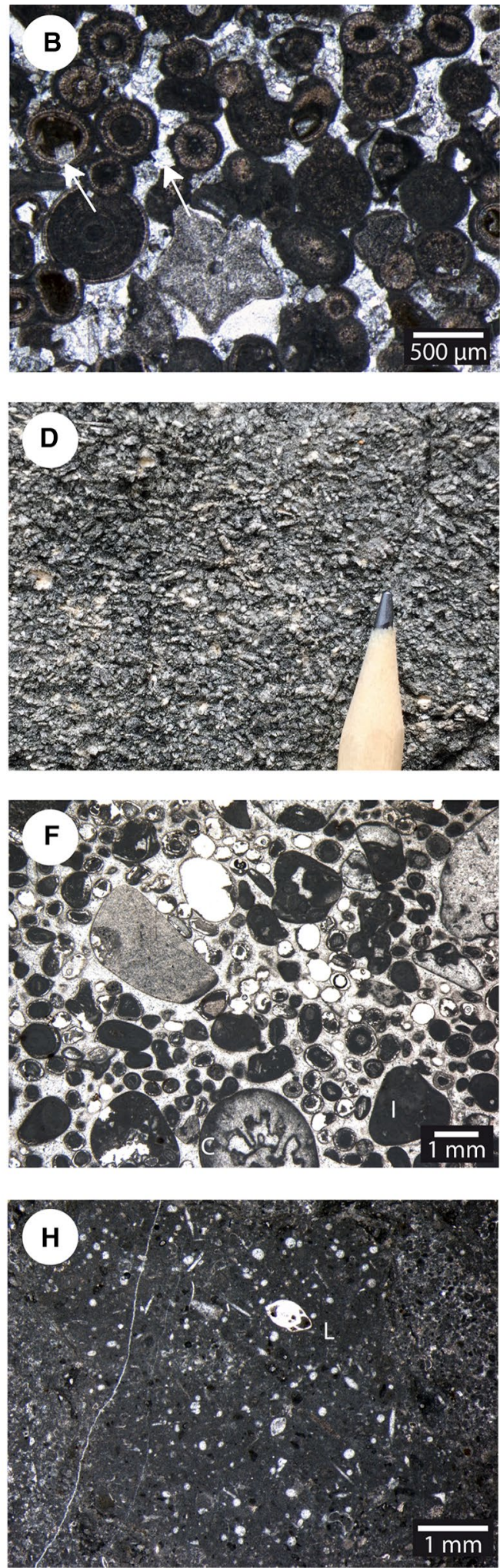

dolomitized, allowing the recognition of the original facies type (facies F1, F2, and F4). In these facies, dolomitization is characterized by post-compaction planar-e-to-planar-s mosaics of dolomite $(20-200 \mu \mathrm{m})$ replacing grains and matrix and 
4Fig. 3 a Outcrop photograph showing herringbone cross-lamination in F1 cross-bedded ooidal-coated grain grainstone-to-packstone. b Photomicrograph of F1 cross-bedded ooidal-coated grain grainstone showing type 3 ooids and type 1 micritic ooid laminae (which form also aggregate grains) and crinoids, partially dolomitized. Arrows point to euhedral dolomite crystals partially replacing the ooid. c Photomicrograph of facies F1 showing grainstone with type 1 micritic ooids alternated with irregular wackestone lenses with sponge spicule wackestone. d Outcrop photograph showing F2 echinoderm packstone-to-grainstone-rudstone. e Photomicrograph of F4-peloidal packstone with echinoderms and thin-shelled bivalves. f Photomicrograph of F5 ooidal grainstone with intraclasts and bioclasts showing type 1 and type 3 ooids, intraclasts (I) and fragments of coral (C) and crinoids, well-cemented by equant blocky calcite cement, with oomouldic porosity. g Ooidal grainstone with intraclasts and bioclasts (F5) showing a compacted fabric with type 1 ooids and intraclasts of clotted peloidal micrite and an isopachous cement rim around grains, precipitated before compaction. h F7 bioturbated peloidal packstoneto-wackestone with sponge spicules and Lenticulina foraminifers (L)

sealing grain contacts (Table 1). In pervasively dolomitized successions, dolomite consists of: (1) type 1 dolomite of planar-s to planar-e mosaics of dull or bright luminescent subhedral to euhedral crystals with size of 30-120 $\mu \mathrm{m}$; and (2) type 2 dolomite (Fig. 8b) with coarser planar-e mosaic of zoned crystals (200-300 $\mu \mathrm{m})$ with a turbid non-luminescent to dull nucleus and an external limpid bright luminescent $\operatorname{rim}($ Fig. 8c, d).

\section{Facies spatial distribution and build-up types}

Vertical and lateral facies distribution and physical correlation among the stratigraphic logs (Fig. 7) allowed distinguishing a lower and an upper part of the succession, characterized by different facies composition (Fig. 9).

The lower part of the studied succession consists of facies from F1 to F4. In the Urzulei Supramonte area (Fig. 9a), it is represented by up to $150 \mathrm{~m}$ of dolomitized carbonates (Figs. 7 and 8), which could not be ascribed to any identified facies due to the replacive dolomitization, capped by $150 \mathrm{~m}$ of partially dolomitized facies F1 cross-bedded ooidal-coated grain grainstone-to-packstone (Fig. 7a). Toward the east (Fig. 7b, c), F1 beds alternate with cross-laminated echinoderm packstone-to-grainstone-rudstone (F2, Genna Scalas), whereas towards south-east (Baunei Supramonte; Fig. 9b), F1 alternates or overlies facies F3-peloidal packstone with ooids and echinoderms and F4-peloidal packstone with chert nodules and thin-shelled bivalves (Genna Ramene, Mt. Oro; Fig. 7b, c). In this south-eastern domain, the succession comprising facies from F1 to F4 (nearly 30-40 m thick; Fig. 7b) directly covers the Hercynian basement and at it is overlain by a sharp facies change with the appearance of bioconstructions (F11, F12) and bioclastic grain-supported facies (F6, F8; Fig. 9b).

The upper portion of the studied succession is characterized by facies from F5 to F13. The boundstone facies (F10,
$\mathrm{F} 11$, and F12) and bioclastic facies (F8, F9) are differently associated forming three types of discrete build-ups (labelled as type 1,2, and 3), which differ for composition, shape, size, and spatial distribution, as displayed in the measured stratigraphic logs (Fig. 7a-c). The type 1 build-up consists of massive coral-stromatoporoid boundstone (F10), overlying and associated with coral-stromatoporoid rudstone-grainstone (F9) and bioclastic packstone-to-grainstone-rudstone with clotted peloidal micrite fragments (F8). In the Urzulei Supramonte area (Iscra, Codula Orbisi, Genna Silana logs; Figs. 7a and 9a), type 1 build-up forms the thickest (45 m) and most laterally continuous (few hundred metres) bioconstruction that thins from Genna Silana westward (Codula Orbisi $20 \mathrm{~m}$, Iscra $2 \mathrm{~m}$ thick) and overlies in the westernmost part (Codula Orbisi, Iscra) facies F5 ooidal grainstoneto-packstone with intraclasts and bioclasts. The top of the coral-stromatoporoid boundstone (F10) is marked by an erosional surface caused by a prolonged subaerial exposure (Fig. 7a).

South-eastward, in the Baunei Supramonte area (Figs. 7b and 9b), the upper part of the succession (35-40 m thick) includes build-ups type 2 (Genna Ramene) and 3 (Mt. Oro) alternated only with the F6 peloidal packstone with reworked intraclasts, bioclasts, and coated grains or with both F6 and F7 peloidal packstone with Lenticulina, respectively. Type 2 build-ups are lens-shaped, 1-2 m thick, and 3-4 m wide, and made of coral-calcareous sponge-diceratid boundstone (F11), including both stromatoporoids and undetermined calcareous sponges, surrounded by bioclastic packstone-to-grainstone-rudstone with clotted peloidal micrite fragments (F8). Type 3 build-ups are lens-shaped or tabular bioconstructions, about $1 \mathrm{~m}$ thick and $1 \mathrm{~m}$ wide, made of calcareous and siliceous sponge-coral-microbialite boundstone (F12) surrounded by bioclastic packstone-tograinstone-rudstone with clotted peloidal micrite fragments (F8). Bioconstructions were not recognized in Baunei Supramonte and Genna Scalas stratigraphic logs (Fig. 7b), where the upper part of the succession is characterized by common fragments of build-up facies reworked in ooidal grainstoneto-packstone with intraclasts and bioclasts (F5), peloidal packstone with reworked intraclasts, bioclasts, and coated grains (F6), and stromatoporoid rudstone-to-packstone with coated grains (F13).

\section{Interpretation}

\section{Depositional model}

The facies distribution observed in the studied Callovian-upper Kimmeridgian carbonate succession of eastern Sardinia allowed recognizing two superimposed depositional phases (phase 1 and 2) characterized by different carbonate 

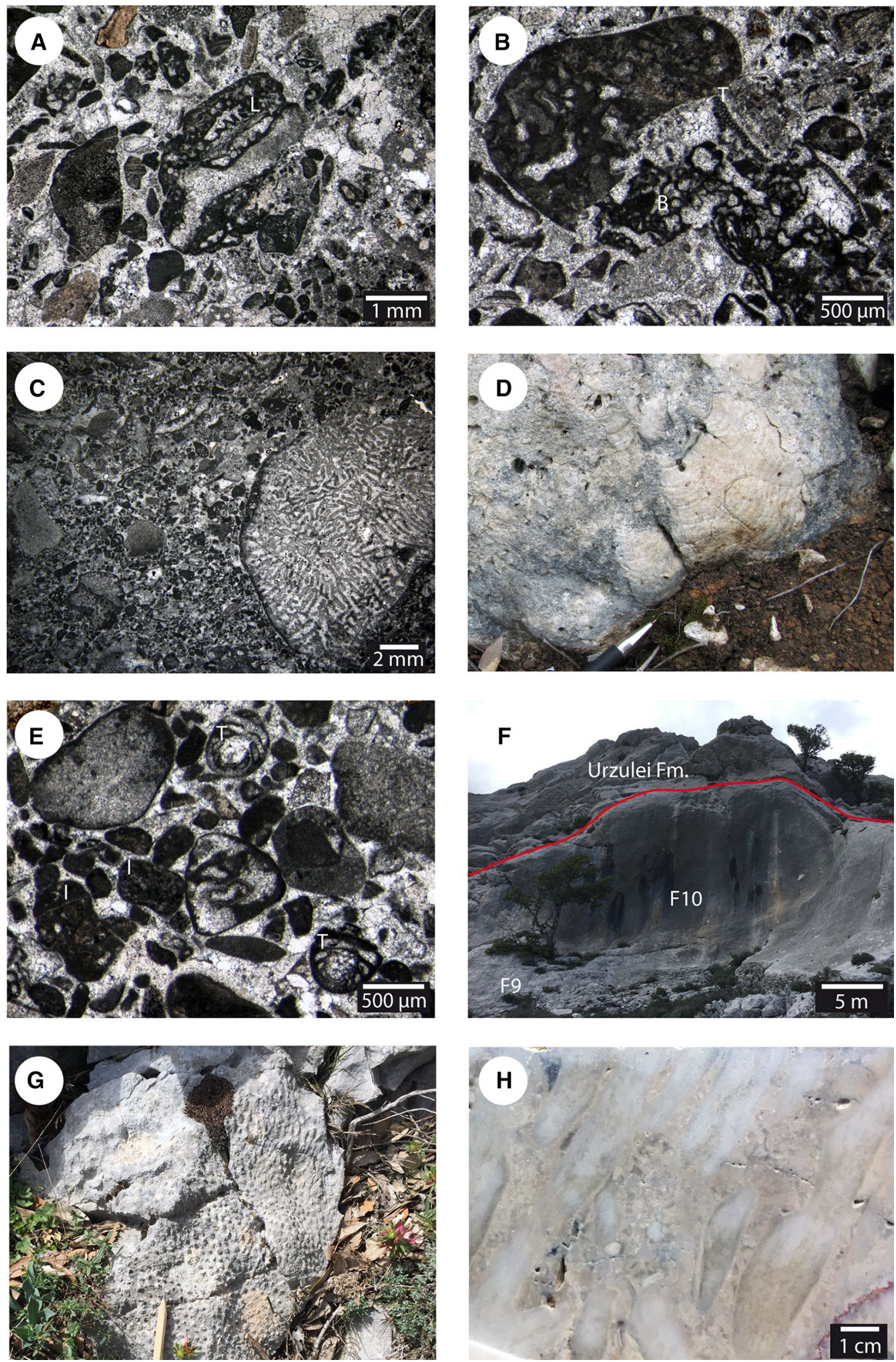

factories and depositional models (Figs. 10 and 11). Phase 1 (lower part of the succession, Dorgali Fm, lower part of Baunei and Mt. Tului formations; Callovian-middle Oxfordian) is characterized by a coated grain-dominated carbonate ramp, encompassing facies from $\mathrm{F} 1$ to $\mathrm{F} 4$, whereas phase 2 (upper part of the succession, upper part of Baunei and Mt. Tului formations; upper Oxfordian-upper Kimmeridgian) represents the development of a carbonate ramp with 
४Fig. 4 a Photomicrograph of facies F8 bioclastic grainstone-to-packstone with clotted peloidal micrite and skeletal fragments, locally encrusted by the microencruster Lithocodium aggregatum (L). b F8 bioclastic grainstone-to-packstone showing an intraclast of clotted peloidal micrite encrusted by Bacinella irregularis (B) and Thaumatoporella parvovesiculifera (T). c Photomicrograph of F9 coralstromatoporoid rudstone-grainstone with bioclasts and intraclasts and a thamnasterioid coral colony. d Outcrop photograph showing centimetre- to decimetre-size stromatoporoids in facies F9. e Photomicrograph of F9 grainstone with bioclasts, intraclasts of clotted peloidal micrite (I) and Trocholina benthic foraminifer (T). f Outcrop photograph showing type 1 build-up composed of coral-stromatoporoid boundstone (F10) overlying coral-stromatoporoid rudstone (F9). g Outcrop photograph of F10 coral-stromatoporoid boundstone showing decimetre-size phaceloid coral colony. h Polished slab of F10 coral-stromatoporoid boundstone with phaceloid coral colony and inter-corallite bioclastic-intraclastic grainstone

coral, stromatoporoid, calcareous, and siliceous sponge and microbialite build-ups (facies from F5 to F13). The phase 1 carbonate ramp dominated by coated grains was characterized by the gradual lateral facies variability common in a low-angle carbonate system (Fig. 9b) with laterally adjacent depositional environments and facies belts (from facies F1 to F4; Fig. 10). The detailed reconstruction of facies architecture in the lower part of phase 1 succession (Dorgali Fm) is frequently prevented by irregularly distributed replacive dolomitization; nevertheless, the local presence of nondolomitized or partially dolomitized strata confirms facies composition from F1 to F4. The petrographic and cathodoluminescence features of the replacive dolomite mosaics suggest that dolomitization took place during burial diagenesis in contact with fluid rich in $\mathrm{Mn}^{2+}$, in reducing environments (cf. Hiatt and Pufahl 2014). The irregular distribution of dolomitization, the thickness variability of the dolomitized portions, the irregular shape of the dolomitization front, and the evidence of dolomite formation post-dating mechanical compaction, suggest that this burial dolomitization partially overprinted the sedimentary succession in proximity of the contact with the Hercynian basement.

Phase 1 cross-bedded ooidal-coated grain grainstone-topackstone (F1) represents ooidal shoals or strand plain in a shallow subtidal environment of the inner ramp, above the effective fair-weather wave base, as demonstrated by the grain-supported texture, well-sorting and sedimentary structures. The presence of herringbone cross-lamination (Fig. 3a) suggests, at least locally, tidal influence on these deposits. The predominance of high-energy type 3 ooids reflects the continuous agitation of the seafloor. Episodes of low-energy sedimentation are demonstrated by thin irregular wackestone beds, suggesting that coated grain shoals were temporarily abandoned, enabling the deposition of mud in protected areas (cf. Samankassou et al. 2003). The cross-laminated echinoderm packstone-to-grainstone-rudstone (F2) was deposited in an open-marine, moderateto-high-energy environment, probably in a deeper setting with respect to $\mathrm{F} 1$, under currents or storms action in a proximal middle-ramp environment. This is suggested by the packstone-to-grainstone texture, good sorting, and cross-lamination. The accumulation of crinoid ossicles can form carbonate sand bars in open-marine, moderate-energy environment on carbonate ramps and at platform margins (cf. Della Porta et al. 2004 and references therein). Facies F3-peloidal packstone with ooids and echinoderms suggests deposition in lower energy environments with respect to F1 and F2. The presence of sparse ooids and echinoderm fragments, frequently broken, suggests that these grains were reworked from adjacent shallower environments. Facies F3 was probably deposited in the middle ramp, not far from ooidal shoals, between fair-weather wave base and storm wave base, where low-energy conditions were occasionally interrupted by storms. Phase 1 more distal deposits consist of peloidal packstone with chert nodules and thin-shelled bivalves (F4). The abundance of micrite matrix and fine grain size that characterize facies F4 suggests deposition in a low-energy environment below the storm wave base. The skeletal biota association suggests open-marine conditions, in particular the presence of thin-shelled bivalves (probably Bositra-like; Molina et al. 2018). Due to the frequent interfingering with middle-ramp facies $\mathrm{F} 3$, this environment could be interpreted as an outer ramp setting.

Phase 2 carbonate ramp is characterized by a change in the carbonate factory (Fig. 11) and the onset of build-up growth (type 1-3) composed of different proportion of colonial or solitary corals, stromatoporoids, chaetetids, undetermined calcareous sponges, siliceous sponges, solenoporaceans, microencrusters, and microbially influenced clotted peloidal and dense micrite precipitates (cf. similar fabrics in Olivier et al. 2003; Della Porta et al. 2013). Microencruster organisms (Bacinella irregularis, Lithocodium aggregatum, Crescentiella morronensis, Thaumatoporella parvovesiculifera) are microfossils, often of incertae sedis, which encrust metazoans and were the focus of numerous studies regarding their taxonomy, palaeoecology, and biostratigraphy (Elliot 1956; Radoičić 1959; Crescenti 1969; Senowbari-Daryan et al. 2008; Dupraz and Strasser 1999; Schlagintweit and Gawlick 2008; Schlagintweit et al. 2010).

During phase 2, the inner ramp was characterized by the deposition of ooidal grainstone-to-packstone with intraclasts and bioclasts (F5). Phase 2 ooidal grainstone (F5) differs from phase 1 ooidal-coated grain grainstone (F1) for the abundance of bioclasts and intraclasts of clotted peloidal micrite. Facies F5 was deposited in a shallow subtidal high-energy environment, likely above the effective fair-weather wave base in the inner ramp. The common occurrence of micritic (type 1) and micritized radial ooids (type 3), formed in the high-energy environment under the continuous agitation of the sea floor, suggests it represents an ooidal shoal. The presence of fragments of 

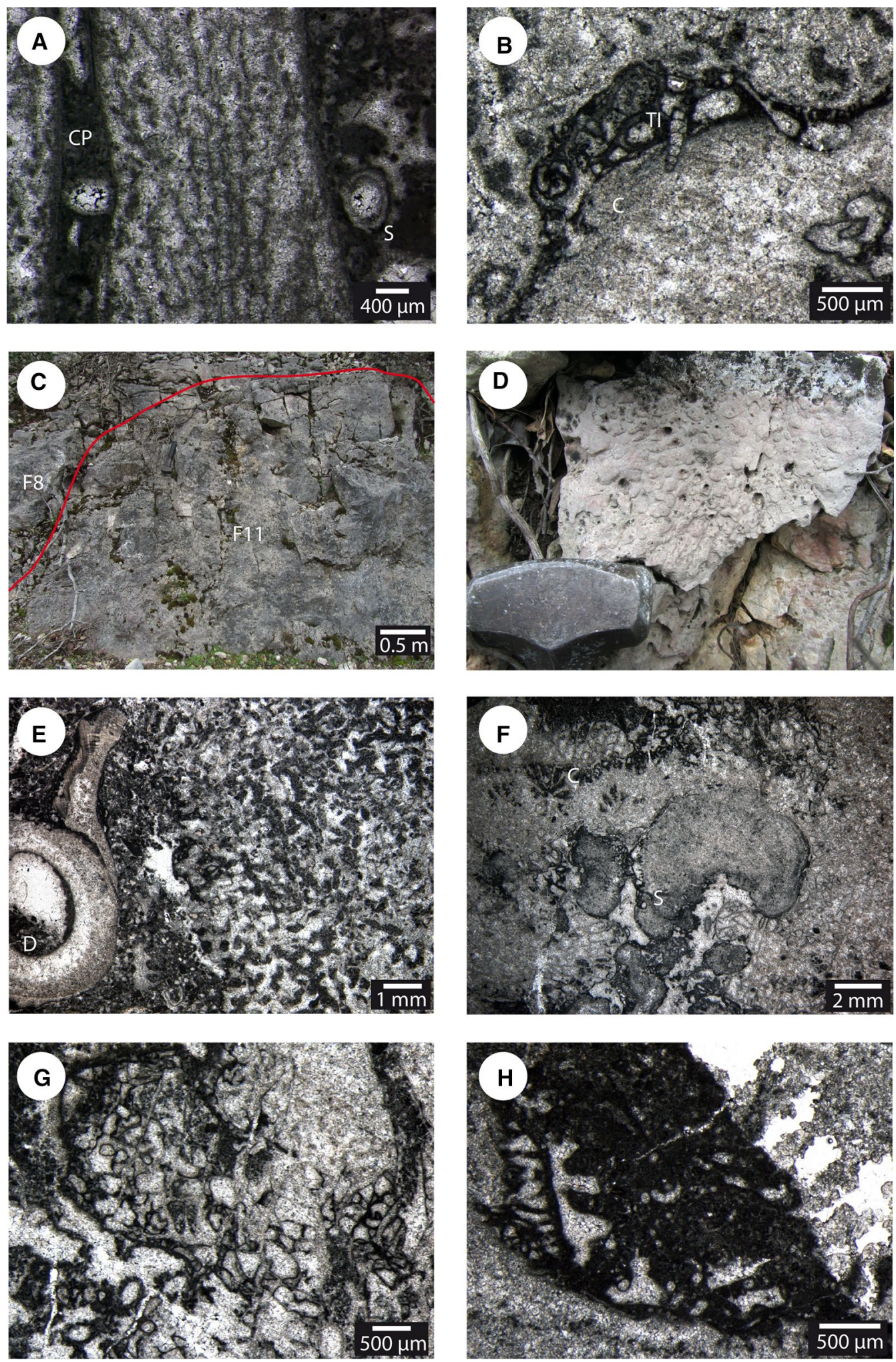

Fig. 5 a Photomicrograph of F10 boundstone with a branching coral colony encrusted by serpulids (S) and clotted peloidal micrite (CP). b F10 thamnasterioid coral (C) encrusted by Bacinella irregularis, clotted peloidal micrite, and the foraminifer Troglotella incrustans (TI). c Outcrop photograph showing type 2 build-up composed of facies F8 bioclastic packstone-to-grainstone-rudstone with clotted peloidal micrite fragments and F11 coral-calcareous sponge-diceratid bound-

stone. d Outcrop photograph of F11 phaceloid coral colony. e Photomicrograph of F11 coral-calcareous sponge-diceratid boundstone with a calcareous sponge and diceratid bivalves (D) with geopetal infill. f F11 boundstone with cerioid coral colony (C) encrusted by solenoporacean (S) and Bacinella irregularis. g Detail of Bacinella irregularis in F11. h Detail of Lithocodium aggregatum in F11 

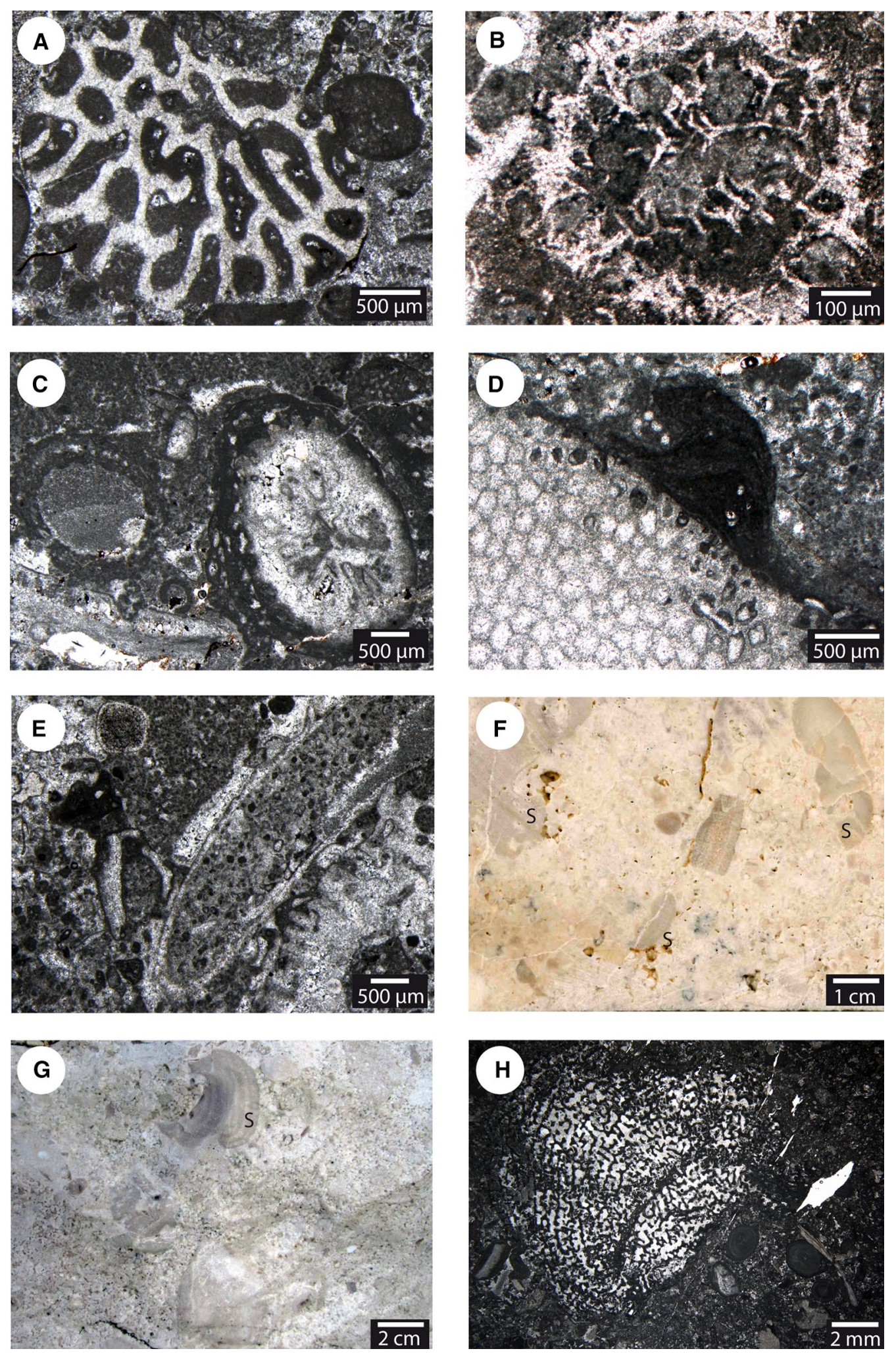

Fig. 6 a Photomicrograph of F12 sponge-coral-microbialite boundstone showing a calcareous sponge fragment. b Facies F12 hexactinellid siliceous sponge. c F12 boundstone with clotted peloidal micrite embedding corals surrounded by dense micrite and microencrusters. d Chaetetid sponge encrusted by Crescentiella morronensis in F12. e F12 sponge-coral-microbialite boundstone with millimetre-

size boring cavities filled by peloidal sediment. f Polished slab photograph of F13 stromatoporoid rudstone-to-packstone with stromatoporoid fragments (S) in a coated grain grainstone-to-packstone. $\mathrm{g}$ Outcrop photograph of F13 stromatoporoids (S) within coated grain grainstone. h F13 stromatoporoid within packstone with coated grains and peloids 


\section{A}

1 ISCRA

2 CODULA ORBISI 3 GENNA SILANA
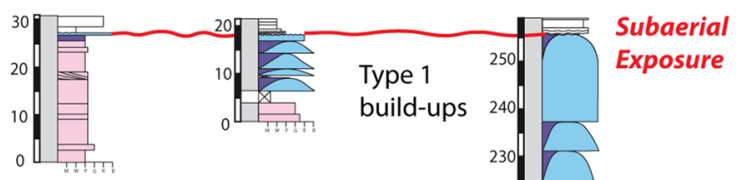

C

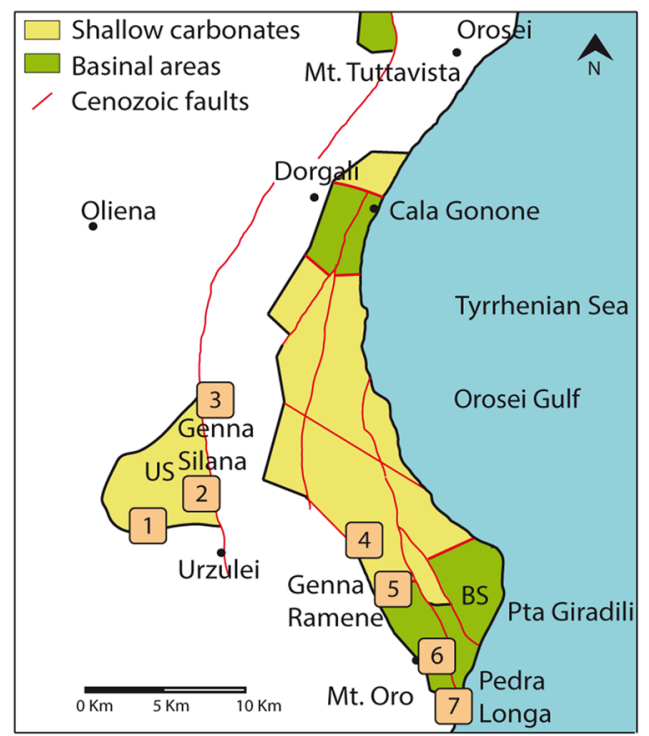

FACIES

Cross-bedded ooidal-coated grain grainstone to packstone (F1)

Cross-laminated echinoderm packstone to grainstone-rudstone (F2)

Peloidal packstone with ooids and echinoderms (F3)

Peloidal packstone with chert nodules and thin-shelled bivalves (F4)

Ooidal grainstone to packstone with intraclasts and bioclasts (F5)

Peloidal packstone with reworked intraclasts, bioclasts and coated grains (F6)

$\square$ Peloidal packstone with Lenticulina (F7)

$\square$ Bioclastic packstone to grainstone-rudstone with clotted peloidal micrite fragments (F8)

- Coral-stromatoporoid rudstone-grainstone (F9)

$\square$ Coral-stromatoporoid boundstone (F10)

$\square$ Coral-calcareous sponge-diceratid boundstone (F11)

Sponge-coral-microbialite boundstone (F12)

$\square$ Stromatoporoid rudstone to packstone with coated grains (F13)

Fabric-replacive dolomitization

LITHOLOGY

$\square$ Limestone $\quad \square$ Partially dolomitized limestone

Dolostone $\square$ Hercynian basement

B 4 GENNA SCALAS

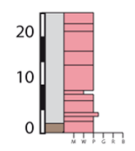

5 GENNA RAMENE

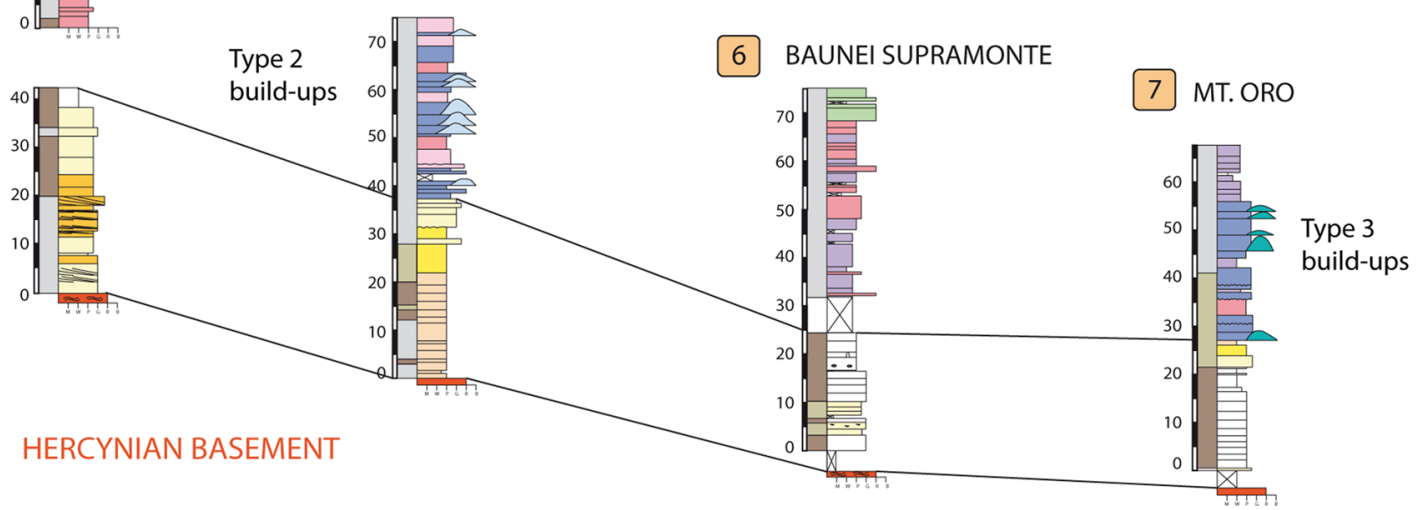


4Fig. 7 a-b Correlation of stratigraphic logs in the NW (Urzulei Supramonte) shallower central area (a) and in the deeper Baunei Supramonte area (b) showing the vertical and lateral distribution of the distinguished facies types (F1-F13) of the studied Callovianupper Kimmeridgian succession. The lower part of the succession includes facies from F1 to F4 belonging to the Dorgali Fm, lower part of Mt. Tului Fm and Baunei Fm. The upper part of the succession comprises facies from F5 to F15 belonging to the upper part of Mt. Tului Fm and Baunei Fm. c Sketch of the study area showing the location of stratigraphic logs

corals and clotted peloidal micrite suggests erosion and reworking of nearby coral-stromatoporoid reefs.

The middle ramp was characterized by the deposition of peloidal packstone with reworked bioclasts and coated grains (F6), the stromatoporoid rudstone-to-packstone with coated grains (F13), and by the development of the coral, stromatoporoid, calcareous, and siliceous sponge build-ups (from F8 to F12). F6 peloidal packstone with reworked bioclasts and coated grains indicates deposition in a subtidal open-marine environment below the fair-weather wave base in the middle ramp. The occurrence of fragmented skeletal and non-skeletal grains indicates reworking of inner ramp sediment and deposition above the storm wave base in a middle-ramp environment. According to Flügel (2004), the benthic foraminifer Trocholina, common in facies F6, is typical of high-energy environments.

In type 1 build-ups (F8, F9 and F10), facies F8 bioclastic packstone-to-grainstone-rudstone with clotted peloidal micrite fragments suggests sedimentation in a relative highenergy environment where most of the grains derive from F10 coral-stromatoporoid boundstone, producing skeletal fragment of reef builders and intraclasts of clotted peloidal and dense micrite. In a similar way, the coral-stromatoporoid rudstone-grainstone (F9) is interpreted as the result of deposition of reefal debris in the higher energy area deriving from the erosion of the build-ups. Indeed, the composition of F9 is similar to F8, with some differences in the size of corals, stromatoporoids, and other calcareous sponges. In the coral-stromatoporoid boundstone (F10), the dimension of coral colonies (reaching $2 \mathrm{~m}$ in width) and the common presence of stromatoporoids suggest a high-energy depositional environment. According to Leinfelder et al. (2005), stromatoporoids were well-adapted to live in high-energy abrasive environments. Type 1 build-ups formed in the proximal middle-ramp environment seaward with respect to the F5 ooidal shoals of the inner ramp (Fig. 11). The widespread presence of debris deriving from the bioconstructions in facies F8 and F9 testifies that they were periodically exposed to storms and currents. San Miguel et al. (2013) interpreted deposits similar to F8 in the Kimmeridgian of the Iberian Basin as derived from storm-induced flows probably below the fair-weather wave base. Debris sheets rich in reefal material were frequently deposited following storm erosion and disintegration of the reefs (Bertling and Insalaco 1998).

Type 2 build-ups (F8 and F11) are similar in composition to type 1 build-ups but are thinner and with reduced lateral continuity. The bioclastic packstone-to-grainstone-rudstone with clotted peloidal micrite fragments (F8) represents the debris deriving from the erosion of F11. In the coral-calcareous sponge-diceratid boundstone (F11), microbialites might have coexisted with the coral growth encrusting intercorallite space and cryptic cavities, as suggested also by Olivier et al. (2003) for Kimmeridgian coral-microbial reefs in the Aquitanian Basin (France) and by Della Porta et al. (2013) for Lower Jurassic coral-calcareous sponge-microbial reefs in the High Atlas (Morocco). The association Lithocodium aggregatum-Bacinella irregularis suggests deposition in the photic zone (Dupraz and Strasser 1999). The presence of stromatoporoids associated with other calcareous sponges and the dominance of phaceloid coral colonies suggest moderate-energy environments. Build-ups type 2 are interpreted as deposited in middle-ramp settings under the action of storm waves associated with peloidal packstone with reworked bioclasts and coated grains (F6; Fig. 11).

In type 3 build-ups (F8 and F12), the presence of siliceous sponges suggests relatively deep environments, because typically during the Jurassic siliceous sponge mounds developed in deep shelves, middle-to-outer ramps or deep slopes, below storm wave base (cf. Pittet and Mattioli 2002; Bartolini et al. 2003; Olivier et al. 2004; Della Porta et al. 2013). This is confirmed by the presence of the microencruster Crescentiella morronensis and relatively lack of the light-dependent association Bacinella-Lithocodium (cf. Dupraz and Strasser 1999) with respect to type 1 and 2 build-ups. Type 3 build-ups lack high-energy stromatoporoids and accumulated in association with peloidal packstone with reworked bioclasts and coated grains (F6) and peloidal packstone with Lenticulina (F7) in distal middle rampto-outer ramp settings. The abundance of the microbially mediated clotted peloidal micrite precipitates in the studied build-ups increases from type 1 to 3 , i.e., towards more distal domains (Mt. Oro). This trend could be observed in other similar depositional systems, such as in the Kimmeridgian carbonate ramps of Spain, where the relative abundance of microbial crusts increases towards deeper settings (San Miguel et al. 2017). The stromatoporoid rudstone-to-packstone with coated grains (F13) was probably deposited in the middle ramp during storm events. Stromatoporoids and ooids were reworked respectively from build-ups type 1 and type 2 and shoals in higher energy environments.

The F7 peloidal packstone with Lenticulina accumulated in a low-energy distal middle-to-outer ramp environment based on the common occurrence of these foraminifers in open-marine distal settings (cf. Hughes 2004). 

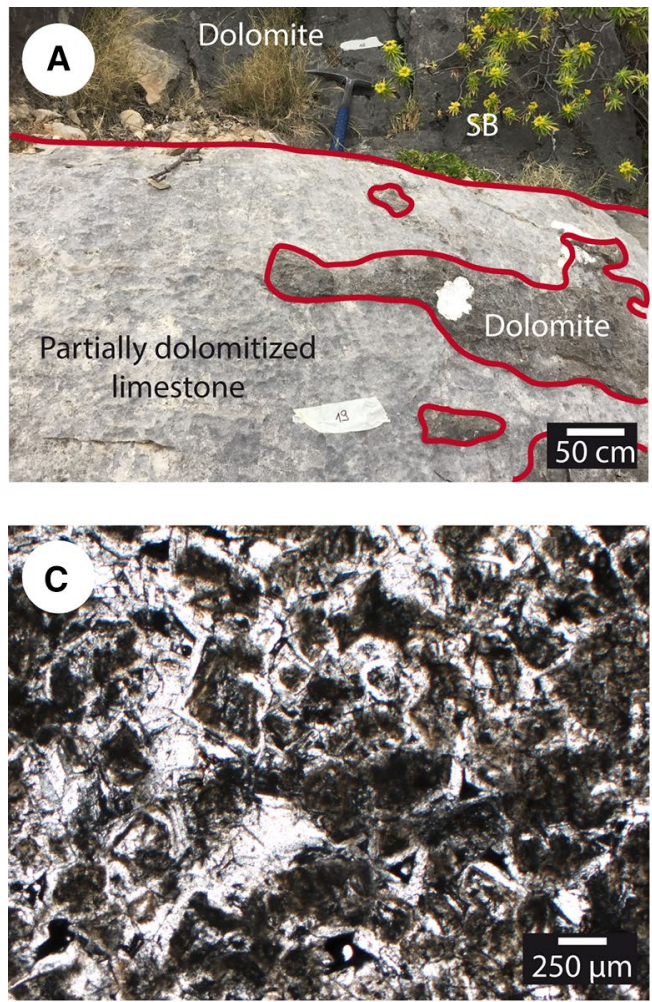

Fig. 8 a Outcrop photograph showing irregular dolomitized areas within limestone and strata-bound (SB) dolomitization (Baunei Supramonte). b Photomicrograph showing a planar-s mosaic of dolomite crystals (DOL-1) and planar-e mosaic of white dolomite crystals in pores (DOL-2) followed by blocky calcite cement (CAL). c Photomicrograph of DOL-2 showing a planar-e mosaic of dolomite crys-

\section{Discussion}

\section{Global controls on Jurassic reefs}

The evolution of Jurassic carbonate platforms was influenced by climatic and oceanographic changes, eustacy, as well as syn-sedimentary tectonics (cf., Merino-Tomé et al. 2012; Brigaud et al. 2014). The extension of Upper Jurassic coral reefs at palaeolatitudes higher than $30 \mathrm{~N}$ and $\mathrm{S}$ suggests that global climate and seawater temperature were generally warm, at least in marine and coastal areas (Hallam 1985; Leinfelder et al. 2002; Sellwood and Valdes 2008). The uniformity of climatic conditions during the whole Jurassic is debated and recently questioned (Dromart et al. 2003; Dera et al. 2011; Jenkyns et al. 2011). The early Oxfordian is considered a relatively cool period characterized by a worldwide crisis of coral reef distribution (Martin-Garin et al. 2012), whereas a climate warming is suggested in the middle Oxfordian on the basis of biogeographical and geochemical data (Cecca et al. 2005; Dera et al. 2011), leading to ice pole melting and eustatic sea-level rise (Dromart et al. 2003). During the warm middle Oxfordian time (Cecca
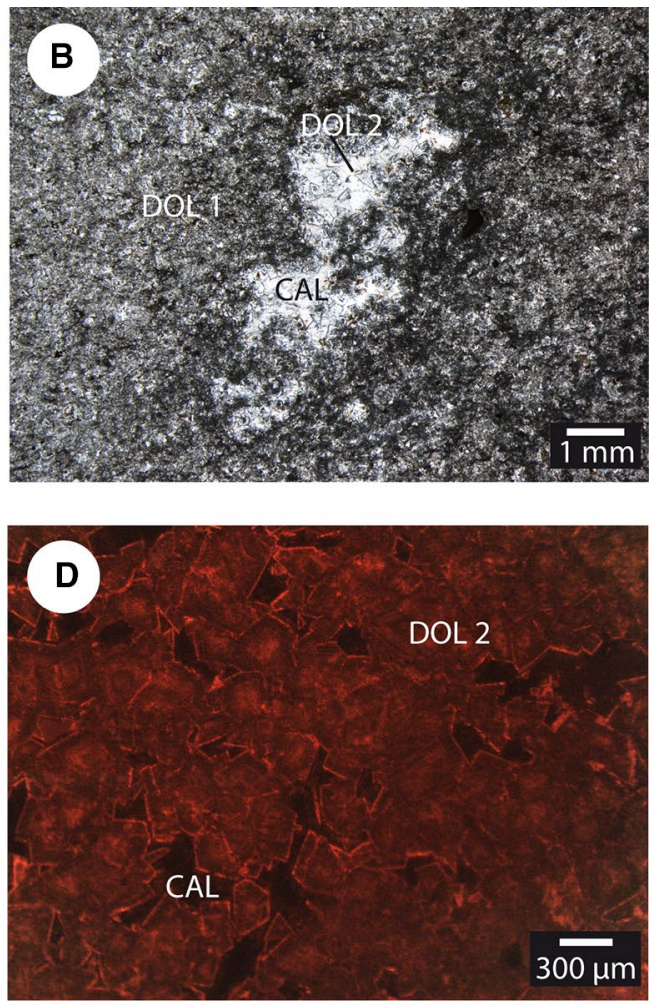

tals with turbid nucleus and limpid external rim. d Photomicrograph in cathodoluminescence microscopy showing a luminescent planar-e mosaic of dolomite crystals (DOL-2), zoned, with a more luminescent external rim and non-luminescent blocky calcite cement in pores (CAL)

et al. 2005), coral reefs expanded towards the northernmost latitudes in the Jurassic $\left(20-35^{\circ} \mathrm{N}\right)$ and were absent at low latitudes close to the Equator (Martin-Garin et al. 2012). The late Oxfordian is considered to be cooler with increased precipitation along the northern Tethys margin, lack of coral reefs at the higher latitudes occupied in the middle Oxfordian, and their shift towards the equatorial belt (Martin-Garin et al. 2012). Nevertheless, according to Dera et al. (2011, 2015), the Late Oxfordian-to-Early Tithonian was a global warming event with acceleration of the hydrological cycle and shifts of the humid belts and locally cooler seawater temperatures might have been related to changes in ocean circulation driven by higher sea-level (Dera et al. 2015). Hence, the global peak of reef distribution and their diversity during middle Oxfordian-to-Kimmeridgian was probably related to optimal environmental conditions favoured by climatic oscillations (Cecca et al. 2005; Martin-Garin et al. 2010; Colombié et al. 2018) and/or by other parameters related to global sea-level and ocean circulation (Kiessling 2009; Dera et al. 2015).

Eustatic sea-level fluctuations likely affected the accommodation for build-up growth: several studies pointed out 

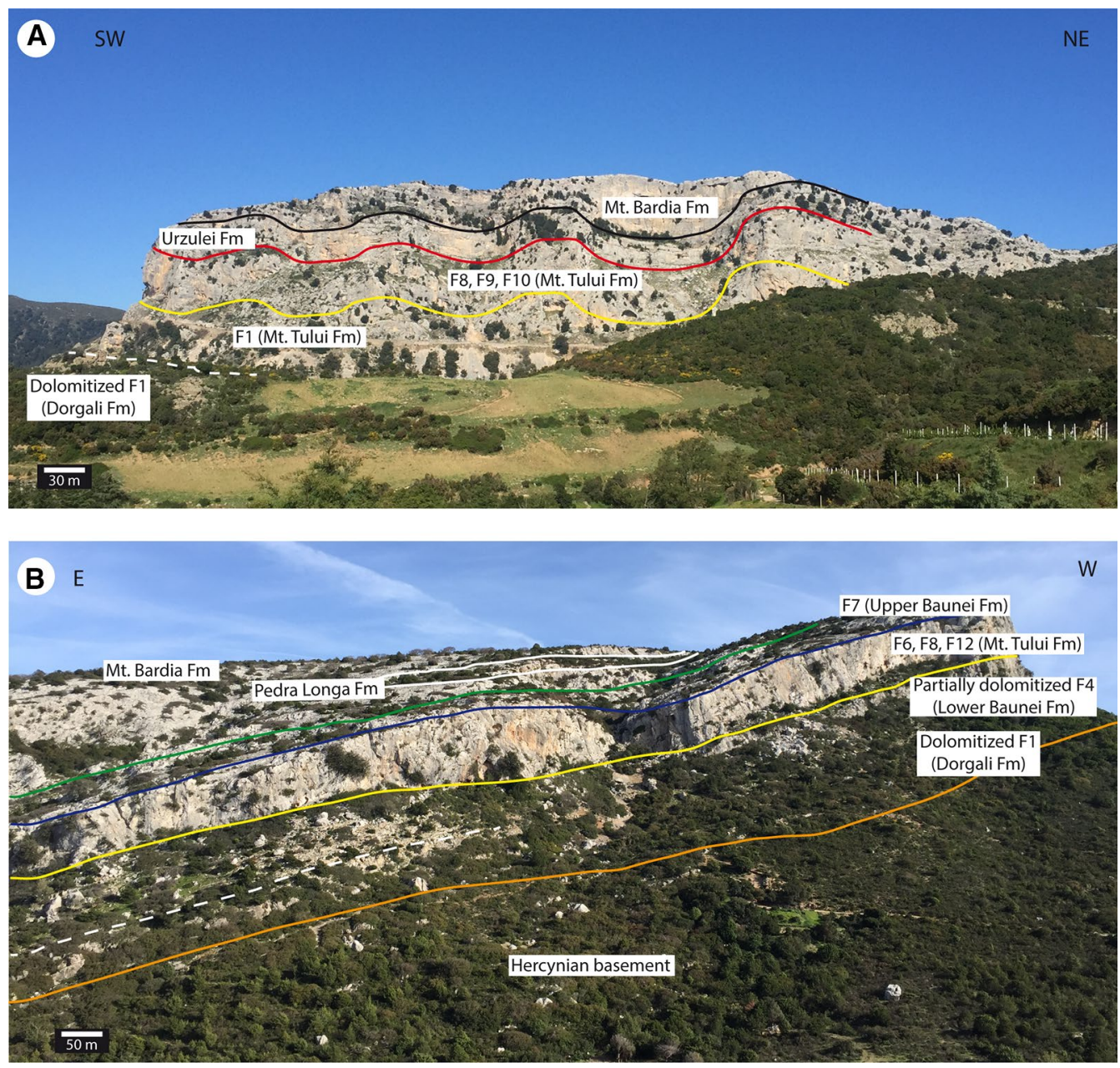

Fig. 9 a Panoramic view of the succession in the NW Urzulei Supramonte (Genna Silana stratigraphic log) showing from base to top: (1) the boundary between the dolomitized (Dorgali Fm) and non-dolomitized (lower Mt. Tului Fm) F1 (white dashed line); (2) the boundary (yellow line) between F1 (phase 1, lower Mt. Tului Fm) and F8, F9, and F10 (phase 2, upper Mt. Tului Fm); and (3) the erosional surface due to subaerial exposure at the top of F8, F9, and F10 (red line) overlain by the Mt. Bardia Fm. b Panoramic view of the succession in the SE Baunei Supramonte (Mt. Oro stratigraphic log) showing

a general global sea-level rise, with oscillations, throughout most of the Jurassic until the Kimmeridgian (Haq et al. 1987; Hardenbol et al. 1998; Hallam 2001; Miller et al. 2005; Haq 2018). Weissert and Mohr (1996) and Miller et al. (2005) identified a sea-level maximum in the late Oxfordian and early Kimmeridgian time, followed by a lowstand in the late Kimmeridgian. On the northern Tethys shelf, the sea-level rise is well reflected by the increase of reef sites during late Oxfordian and early Kimmeridgian (Leinfelder et al. 2002). The evolution of eastern Sardinia carbonate system from a coated grain-dominated carbonate ramp (phase 1) to a reef-bearing ramp (phase 2) is likely related to the global spread of reefs with corals, stromatoporoids, calcareous and siliceous sponges, and microbialites driven by the from base to top: (1) the top of the Hercynian basement (orange line); (2) the boundary (yellow line) between the lower part of the succession including dolomitized and partially dolomitized F1 and F4 strata (phase 1, Dorgali Fm and lower Baunei Fm) and the upper of the succession made of facies F6, F8, and F12 (phase 2, Mt. Tului Fm); (3) the boundary (blue line) between F6, F8, and F12 (phase 2; Mt. Tului Fm) and the overlying facies F7 (phase 2, upper Baunei Fm); (4) the top of the studied succession (green line) and the overlying Pedra Longa and Mt. Bardia formations (cf. Figure 1c)

middle Oxfordian-Kimmeridgian climatic fluctuations and sea-level rise.

\section{Comparison of eastern Sardinia build-ups with coeval reefs}

The distribution of phase 2 build-up types with corals, diverse sponges, microencrusters, and microbialites in the eastern Sardinia ramp fits well with the model proposed for the Late Jurassic "reef window" by Leinfelder et al. (2002). According to Leinfelder et al. (2002), three basic intergrading reef types existed throughout the Jurassic: siliceous sponge reefs, microbialite reefs, and scleractinian coral and stromatoporoid reefs. The first two types developed 

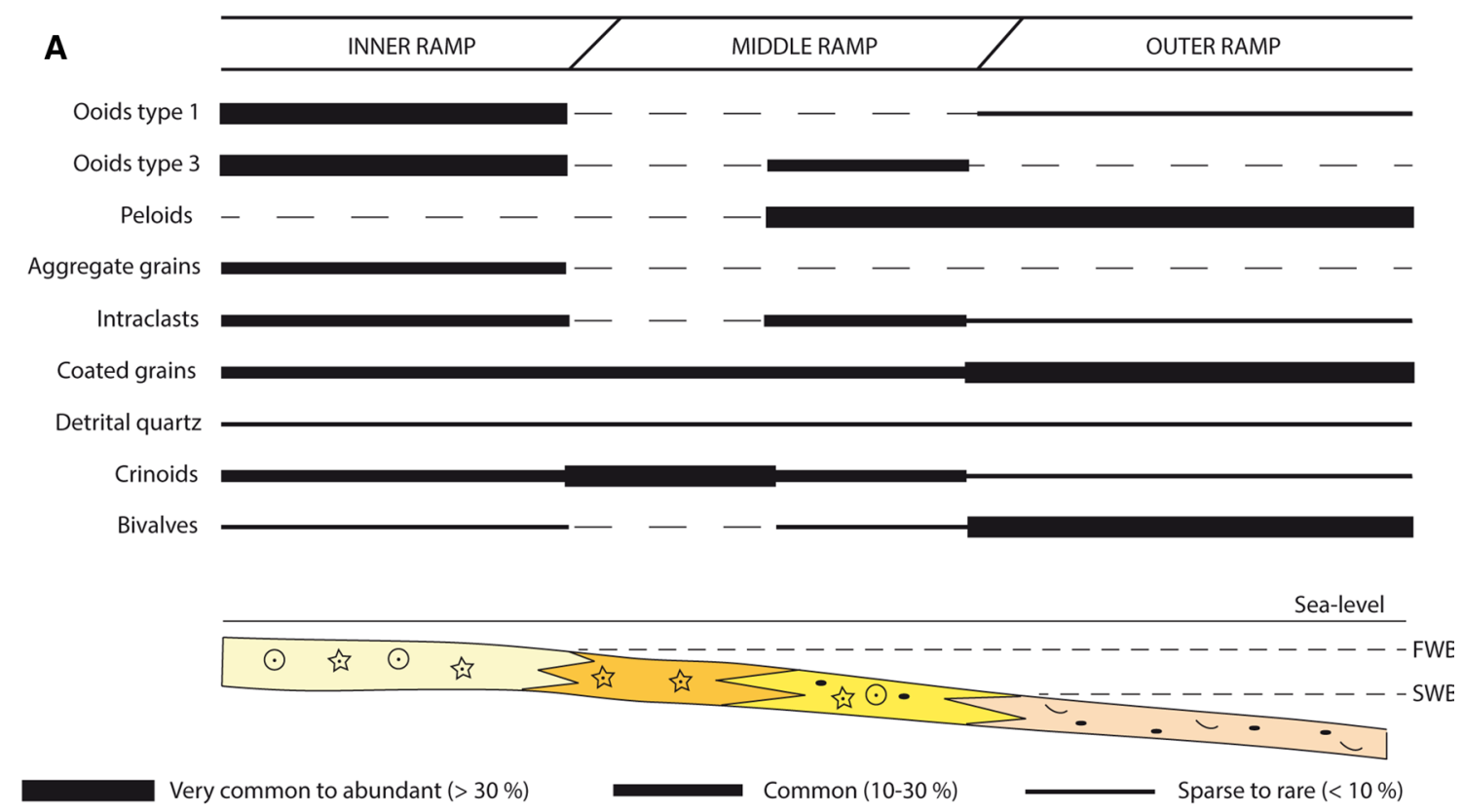

LEGEND

$\square$ Cross-bedded ooidal-coated
grain grainstone to packstone (F1)
$\begin{aligned} & \text { Cross-laminated echinoderm } \\ & \text { packstone to grainstone-rudstone (F2) }\end{aligned}$
$\square \begin{aligned} & \text { Peloidal packstone with ooids } \\ & \text { and echinoderms (F3) }\end{aligned}$
$\begin{aligned} & \text { Peloidal packstone with chert } \\ & \text { nodules and thin-shelled bivalves (F4) }\end{aligned}$
$\odot$ Ooids $\quad$ Echinoderms
- Peloids $\quad \longrightarrow$ Thin shelled
bivalves

Fig. 10 a Semi-quantitative analysis of the carbonate components for different depositional environments and 2D interpretative depositional model of phase 1 . b Schematic sketch showing the spatial distribution of the depositional environments in phase 1 carbonate ramp

in distal middle-to-outer ramp settings, whereas the scleractinian coral reefs developed at shelf margins or in shallow middle ramp environments (Crevello and Harris 1984; Leinfelder 1993b; Leinfelder et al. 2002). Coral-stromatoporoid-microbialite reefs and coral-debris reefs developed around or above storm wave base, whereas siliceous sponge mounds and microbialite reefs occurred in deeper, below storm wave base, settings (Leinfelder et al. 2002).

The Upper Jurassic coral-stromatoporoid, siliceous sponge, and microbialite reefs' distribution was governed by mechanisms different from present-day reefs. The reef dominated by ooidal-coated grain grainstone facies. Approximate location of stratigraphic logs in Fig. 7: 1-Iscra; 2-Codula Orbisi; 3-Genna Silana; 4-Genna Scalas; 5-Genna Ramene; 6-Supramonte Baunei; 7-Mt. Oro

window in the Late Jurassic was relatively wide (Leinfelder et al. 2002): corals thrived both in mesotrophic and oligotrophic settings, because the photosymbiontic relationship with zooxanthellae was probably far from being perfect in the Jurassic (Nose and Leinfelder 1997; Leinfelder et al. 2002). Many coral taxa likely required a higher amount of particulate nutrients and reef settings were influenced by fine siliciclastic input that may have reflected the importance of heterotrophic nutrition for corals (Nose and Leinfelder 1997). Stromatoporoids could be 

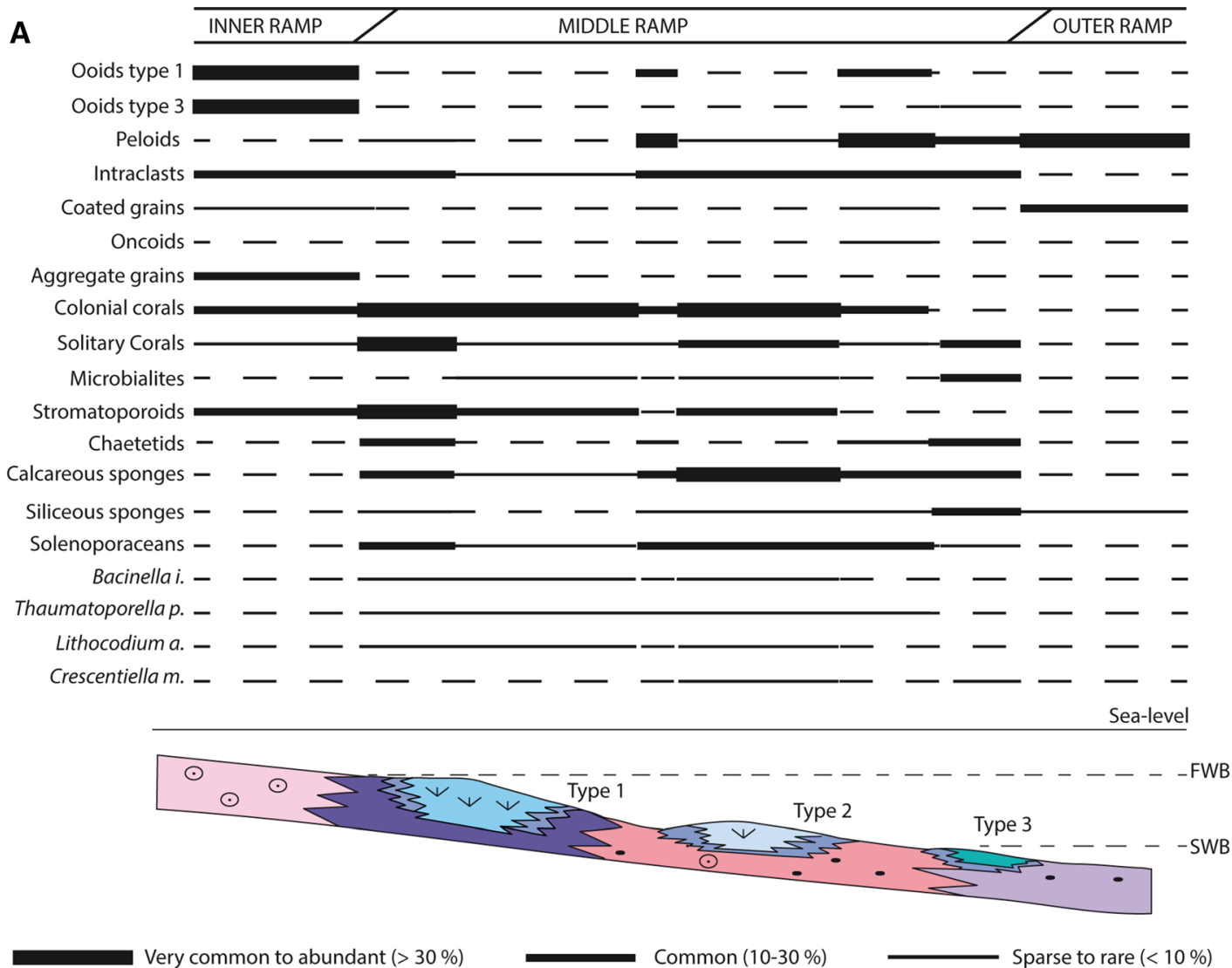

LEGEND

Ooidal grainstone to packstone with intraclasts and bioclasts (F5)

Peloidal packstone with reworked intraclasts, bioclasts and coated grains (F6)

Peloidal packstone with Lenticulina (F7)

Bioclastic packstone to grainstone-rudstone with clotted peloidal micrite fragments (F8)

Coral-stromatoporoid rudstone-grainstone (F9)

Coral-stromatoporoid boundstone (F10)

Coral-calcareous sponge-diceratid boundstone (F11)

Sponge-coral-microbialite boundstone (F12)

Stromatoporoid rudstone to packstone with coated grains (F13)

$\odot$ Ooids $\vee$ Corals

- Peloids $\nsucc$ Reworked corals

Fig. 11 a Semi-quantitative analysis of the carbonate components for different depositional environments and 2D interpretative depositional model of phase 2. b Schematic sketch showing the spatial distribution of the depositional environments in phase 2 carbonate ramp

associated with or result dominant in coral reefs in highenergy oligotrophic settings (Leinfelder et al. 2005).

Build-ups of eastern Sardinia represent a mixture between these end-member reef types and their distribution along

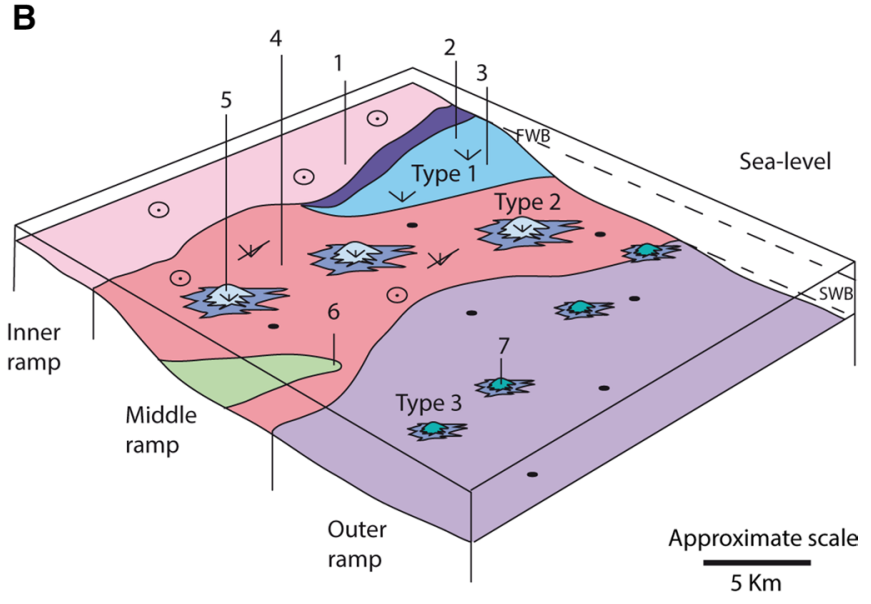

with build-ups type 1-3. Approximate location of stratigraphic logs in Fig. 7: 1-Iscra; 2-Codula Orbisi; 3-Genna Silana; 4-Genna Scalas; 5-Genna Ramene; 6-Supramonte Baunei; 7-Mt. Oro

the carbonate ramp reflects the modelled global distribution of coral-stromatoporoid, calcareous and siliceous sponge, and microbialite reefs. Type 1 (F8, F9, and F10) and 2 (F8 and F11) reefs represent coral reefs with stromatoporoids, 
chaetetids, various calcareous sponges, diceratid bivalves, and microbialite contribution, whereas type 3 build-ups (F8 and F12) are a mixture between siliceous sponges and coral-microbialite reefs, lacking stromatoporoids.

During the Late Jurassic, reefs with corals, stromatoporoids, calcareous or siliceous sponge, and microbialites developed in the Alpine Tethys (Fig. 2) and in the Central Atlantic. Reefs from these palaeogeographic settings show differences in terms of composition, geometries, and distribution along the depositional profile. The build-up types of eastern Sardinia display similarities and differences with coeval reefs from all these palaeogeographic settings.

As for the eastern Sardinia reefs, the northern Tethys reefs mainly developed on carbonate ramps in middle ramp settings exposed to the effect of storm waves, seaward of ooidal shoals representing the inner ramp facies belt. On the western margin of the Iberian Basin during the Kimmeridgian (Aurell et al. 2003; Alnazghah et al. 2013), pinnacle reefs are reported in the middle ramp (San Miguel et al. 2017), with similar composition but different geometry with respect to the type 2 lens-shaped build-ups of eastern Sardinia. Carbonate ramps with ooidal shoals in the inner ramp and coral-microbial reefs in middle-ramp environment are reported from the Oxfordian of the French Jura and Paris Basin (Burgundy, Armorican and Lorraine platforms), where an epicontinental sea flooded the area among scattered emerged lands (Bertling and Insalaco 1998; Lathuilière et al. 2005; Olivier et al. 2011; Brigaud et al. 2014; Olivier 2019).

Carbonate-producing biota associations are different in the northern Tethys coral-microbialite reefs that generally lack stromatoporoids (Leinfelder et al. 2002; Kiani Harchegani and Morsilli 2019) with respect to eastern Sardinia reefs. This is considered to be due to lower water temperatures and scarce adaptation of stromatoporoids to mesotrophic conditions driven by high terrestrial run-off (Leinfelder et al. 2002, 2005). Exceptions are bioherms of chaetetids and Cladocoropsis mirabilis in lagoon and backshoal environments (e.g., Spain, Sequero et al. 2019) and some coral-stromatoporoid-microbialite mounds in the Kimmeridgian of central Spain (Pomar et al. 2015). The microbial contribution to reef growth appears to be higher during the Oxfordian-Kimmeridgian in French (Olivier et al. 2003) and Spanish (San Miguel et al. 2017) reefs than in the eastern Sardinia build-up types.

Type 3 build-ups lack stromatoporoids and contain calcareous and siliceous sponges; the latter typically formed mounds in the northern Tethys in middle-to-outer ramp settings (Leinfelder 1993b; Leinfelder et al. 2002). Among the most important occurrences of Upper Jurassic siliceous sponge build-ups, there were the Swabian and Franconian Alb (Oxfordian-Kimmeridgian) of southern Germany (Pittet and Mattioli 2002; Bartolini et al. 2003; Olivier et al. 2004), where siliceous sponge reefs formed isolated mounds on a homoclinal ramp. In the Oxfordian of Southern Spain, siliceous sponge-microbial bioconstructions developed in lowenergy, nutrient-rich conditions (Olóriz et al. 2003a, b, 2006, 2012; Reolid et al. 2005, 2007). Other coeval examples in similar depositional conditions were described in Poland (Trammer 1989; Matyszkiewicz et al. 2012) and Romania (Franţescu 2011). In eastern Sardinia, type 3 build-ups were probably formed in an ecological window overlapping between coral-stromatoporoid and siliceous sponge and microbialite environmental demands.

The Oxfordian-Kimmeridgian intra-Tethys reefs present similarities with eastern Sardinia reefs type 1 and 2 and show a different distribution pattern with respect to northern Tethys (Leinfelder et al. 2002). The characteristics of the intra-Tethys reefs are related to a structural setting deriving from extensional tectonics and lack of terrigenous input reaching the isolated platforms, favouring oligotrophic conditions (Leinfelder et al. 2002). The Upper Jurassic intraTethys reefs are characterized by abundant stromatoporoids and various calcareous sponges and reef zonation (Kiani Harchegani and Morsilli 2019). For instance, in the Oxfordian-Kimmeridgian of Croatia (Turnšek et al. 1981), the reef complex consists of a back-reef lagoon with Cladocoropsis patch reefs, a high-energy zone dominated by stromatoporoids, and a lower energy one dominated by coral-chaetetid facies. Other examples of zoned reefs dominated by stromatoporoids are reported in the central Apennine (Kimmeridgian-Tithonian, Ellipsactinia Limestone; Rusciadelli et al. 2011), Apulian carbonate platform (Kiani Harchegani and Morsilli 2019), Sicily (Tithonian-Valanginian, Basilone and Sulli 2016), Friuli Platform in northern Italy (Upper Jurassic; Picotti and Cobianchi 2017), and Northern Calcareous Alps (Austria, Kimmeridgian-Berriasian; Schlagintweit and Gawlick 2008). The contribution of stromatoporoids, chaetetids, and undetermined calcareous sponges in the eastern Sardinia type 1 and type 2 build-ups is important, even though corals dominate. Nevertheless, the geometry of isolated platforms of the Alpine Tethys differs from eastern Sardinia carbonate ramp because of the different structural setting. The intra-Tethys platforms are characterized by tectonically controlled high-relief steep margins, with stromatoporoid-rich reefs developing at high-energy platform margin and coral-stromatoporoid patch reefs and microencruster-cement crust boundstone characterizing the fore-reef slope (Schlagintweit and Gawlick 2008).

Differently from eastern Sardinia and other settings, in the southern Tethys extensive epeiric platform of the Arabian Peninsula, the bioconstructions were dominated by stromatoporoids and corals were not important reef builders (Hughes et al. 2008). This was likely controlled by high water temperature and oligotrophy in arid climate. Among stromatoporoids, the most widespread was 
Cladocoropsis mirabilis in shallow protected lagoons (Hughes et al. 2008). The Oxfordian reefs of the Hanifa Fm represent an exception, because mixed coral-stromatoporoid bioconstructions are similar in composition to the eastern Sardinia type 1 and type 2 reefs, developed as well in middle-ramp environment (Fallatah and Kerans 2018).

The eastern Sardinia build-up types 1-3 with corals, stromatoporoids, calcareous and siliceous sponges, and microbialites show some similar characters with reefs developed on carbonate systems in the Atlantic province in the Gulf Coast and Portugal.

Subsurface data from the Oxfordian Smackover Fm (U.S. Gulf Coast) show ooidal shoals in the inner ramp facing siliceous and calcareous sponge, coral, and microbialite reefs in the middle ramp (Crevello and Harris 1984) and coral-stromatoporoid reefs in higher energy settings. The depositional model suggested for the Smackover Fm resembles that proposed for phase 2 of eastern Sardinia. The siliceous and calcareous sponge, coral, and microbialite build-ups formed in moderately agitated environment and show variability in composition related to bathymetry, with increasing abundance of siliceous sponges with depth and increase in coral content in shallower environments (Baria et al. 1982; Crevello and Harris 1984). Transitional reefs (coral-siliceous sponge reefs) formed at intermediate depths between the pure siliceous sponge mounds and the coral-microbial reef environments, as observed in type 3 reefs of eastern Sardinia. Coral-stromatoporoid reefs in high-energy settings are similar in composition to type 1 build-ups. The eastern part of the North Atlantic province (Portugal) is represented by a wide variety of reefs developed in diverse structural settings. The most similar to the eastern Sardinia reefs developed in carbonate ramps (e.g., Algarve Basin, Oxfordian-Kimmeridgian; Leinfelder 1993a) where coral reefs with debris deposits developed in the distal part of the inner ramp, mixed coral-siliceous sponge reefs accumulated in the middle ramp and microbial or siliceous sponge mounds occurred mostly in the outer ramp (Leinfelder 1993a). In the Atlantic province, there are also reefs developed in structural settings different from eastern Sardinia showing less similarities with eastern Sardinia type reefs. Examples are the coral-calcareous sponge reefs with stromatoporoids and chaetetids developed at the margin of high-relief platforms in the Oxfordian-Kimmeridgian of the Abenaki Fm along the shelf of Eastern Canada (Nova Scotia; Jansa et al. 1988; Pratt and Jansa 1988), in Ota (Portugal, Kimmeridgian, Leinfelder 1992; Nose 1995), in the Oxfordian-Kimmeridgian coral-microbialite reefs developed at the margin of a tilted block in the eastern margin of the North Atlantic (Morocco, Ourribane et al. 2000; Martin-Garin et al. 2007; Olivier et al. 2012) or coral patch reefs occurring on coastal siliciclastic shelves (Portugal, Leinfelder 1993a).

\section{Controls on eastern Sardinia reef growth}

The development of build-ups in the late Oxfordian-late Kimmeridgian (phase 2) carbonate ramp of eastern Sardinia is mostly controlled by light availability and water energy. The distribution of different build-up types reflects the bathymetric position, showing important variations of composition and geometry related to water depth. The interplay of light penetration and hydrodynamic energy controlled the composition of the build-ups. Type 1 coral-stromatoporoid build-ups developed in the proximal middle ramp, whereas lens-shaped coral-calcareous sponge-diceratid type 2 build-ups, including stromatoporoids, formed in distal middle-ramp settings. Type 3 coral-calcareous and siliceous sponge-microbialite buildups lacking stromatoporoids formed in deeper middle-toouter ramp environments, in lower energy and reduced light, where siliceous sponges, indicative of deeper depositional environments (Gaillard 1983; Crevello and Harris 1984; Leinfelder 1993b; Della Porta et al. 2013), were common, associated with microbially influenced clotted peloidal micritic precipitates. The bathymetric control on the distribution of different reef types reflects the control on the coeval reef distribution within carbonate ramps in northern Tethys and some carbonate platforms in the Atlantic region (Crevello and Harris 1984; Leinfelder 1993a; Leinfelder et al. 2002; Della Porta et al. 2013; Kiani Harchegani and Morsilli 2019).

A secondary control on build-up composition could be nutrient level. The absence of stromatoporoids in coral reefs is considered to be indicative of mesotrophic environments and siliciclastic input in the northern Tethys (Leinfelder et al. 2005). Instead, the contemporaneous occurrence of stromatoporoids and chaetetids is suggested as indicative of oligotrophic settings (Leinfelder et al. 2005). The abundance of stromatoporoids in the intraTethys platforms is interpreted as a consequence of the oligotrophic conditions related to scarce siliciclastic input in isolated platforms (Leinfelder et al. 2005).

The composition of the eastern Sardinia upper Oxfordian-upper Kimmeridgian reefs is enriched in stromatoporoids, chaetetids, and undetermined calcareous sponges with respect to other northern Tethys coeval reefs. This evidence may suggest for eastern Sardinia reduced nutrient levels and terrestrial run-off with respect to the mesotrophic conditions of the coeval northern Tethys attached carbonate ramps such as those in Spain (Bádenas and Aurell 2010; San Miguel et al. 2017), France (Lathuiliere et al. 2005; Olivier et al. 2011), Swiss Jura (Dupraz and Strasser 1999, 2002), and Germany (Olivier et al. 2004). 


\section{Conclusions}

The sedimentological study of the Callovian-upper Kimmeridgian portion of the eastern Sardinia Jurassic-Lower Cretaceous carbonate succession (Dorgali, Mt. Tului and Baunei formations) allowed distinguishing 13 depositional facies belonging to two superimposed carbonate ramp phases. The carbonate system evolved from a coated grain-dominated carbonate ramp (phase 1; Callovian-middle Oxfordian) to a reef-bearing carbonate ramp (phase 2; upper Oxfordian-upper Kimmeridgian). The evolution of the carbonate ramp reflects the global middle Oxfordian-early Kimmeridgian increase in reef diversity and distribution, driven by sea-level rise and climatic fluctuations. During phase 2, three different build-up types were identified, largely controlled in terms of composition and spatial distribution by bathymetry that influenced light penetration levels and water energy as in coeval northern Tethys and Atlantic carbonate systems. Coral-stromatoporoid and coral-calcareous sponge-diceratid reefs with stromatoporoids (build-up type 1 and 2) developed in middle ramp, intermittent high-energy environments, exposed to the reworking effect of storm currents, whereas calcareous and siliceous sponge-coral-microbialite reefs lacking stromatoporoids (type 3) developed in lower energy environments in the distal middle-to-outer ramp. The abundance of stromatoporoids, chaetetids, and undetermined calcareous sponges in build-up type 1 and 2 differentiate the eastern Sardinia upper Oxfordian-upper Kimmeridgian reefs from the coeval northern Tethys reefs, likely due to reduced nutrient availability and terrestrial run-off in eastern Sardinia with respect to the northern Tethys shelves. Thus, the eastern Sardinia carbonate ramp represents a transitional reef realm bridging the attached northern Tethys platforms and the isolated intra-Tethys platforms.

Acknowledgements The authors warmly thank Flavio Jadoul for introducing to the study area and stimulating discussions. Curzio Malinverno (University of Milan) is thanked for thin section preparation, and Lorenzo Cariati and Ilaria Menga for support in the field. The authors wish to thank Editor-in-Chief Wolfgang Kiessling, Marcos Aurell, and an anonymous reviewer for the careful and highly detailed reviews that greatly improved the manuscript.

Funding Open access funding provided by Università degli Studi di Milano within the CRUI-CARE Agreement. Financial support was provided by PhD grant from University of Milan and MUR Ministry of University.

\section{Compliance with ethical standards}

Conflict of interest There are no conflicts of interests and data are available on request from the authors.
Open Access This article is licensed under a Creative Commons Attribution 4.0 International License, which permits use, sharing, adaptation, distribution and reproduction in any medium or format, as long as you give appropriate credit to the original author(s) and the source, provide a link to the Creative Commons licence, and indicate if changes were made. The images or other third party material in this article are included in the article's Creative Commons licence, unless indicated otherwise in a credit line to the material. If material is not included in the article's Creative Commons licence and your intended use is not permitted by statutory regulation or exceeds the permitted use, you will need to obtain permission directly from the copyright holder. To view a copy of this licence, visit http://creativecommons.org/licenses/by/4.0/.

\section{References}

Al-Husseini MI (1997) Jurassic sequence stratigraphy of the western and southern Arabian Gulf. GeoArabia 2:361-382

Alnazghah MH, Bádenas B, Pomar L, Aurell M, Morsilli M (2013) Facies heterogeneity at interwell-scale in a carbonate ramp, Upper Jurassic, NE Spain. Mar Pet Geol 44:140-163. https:// doi.org/10.1016/j.marpetgeo.2013.03.004

Amadesi E, Cantelli C, Carloni GC, Rabbi E (1961) Ricerche geologiche sui terreni sedimentari del Foglio 208-Dorgali. Giorn Geol 28:59-87

Aurell M, Robles S, Bádenas B, Rosales I, Quesada S, Meléndez G, Garcia-Ramos JC (2003) Transgressive-regressive cycles and Jurassic palaeogeography of northeast Iberia. Sediment Geol 162:239-271. https://doi.org/10.1016/S0037-0738(03)00154-4

Baccelle L, Bosellini A (1965) Diagrammi per la stima visiva della composizione percentuale delle rocce sedimentarie. Ann Uni Ferrara, NS, Sez IX; Sci Geol Paleontol 1:59-62

Bádenas B, Aurell M (2010) Facies models of a shallow-water carbonate ramp based on distribution of non-skeletal grains (Kimmeridgian, Spain). Facies 56:89-110. https://doi.org/10.1007/ s10347-009-0199-z

Baria LR, Stoudt DL, Harris PM, Crevello PD (1982) Upper Jurassic reefs of Smackover formation, United States gulf coast. Am Assoc Pet Geol Bull 66:1449-1482. https://doi. org/10.1306/03b5a96c-16d1-11d7-8645000102c1865d

Bartolini A, Pittet B, Mattioli E, Hunziker JC (2003) Shallowplatform palaeoenvironmental conditions recorded in deepshelf sediments: $\mathrm{C}$ and $\mathrm{O}$ stable isotopes in Upper Jurassic sections of southern Germany (Oxfordian-Kimmeridgian). Sediment Geol 160:107-130. https://doi.org/10.1016/S0037 $-0738(02) 00369-X$

Basilone L, Sulli A (2016) A facies distribution model controlled by a tectonically inherited sea bottom topography in the carbonate rimmed shelf of the Upper Tithonian-Valanginian Southern Tethyan continental margin (NW Sicily, Italy). Sediment Geol 342:91-105. https://doi.org/10.1016/j.sedgeo.2016.06.013

Bertling M, Insalaco E (1998) Late Jurassic coral/microbial reefs from the northern Paris Basin-facies, palaeoecology and palaeobiogeography. Palaeogeogr Palaeoclimatol Palaeoecol 139:139-175

Beutel EK, Nomade S, Fronabarger AK, Renne PR (2005) Pangea's complex breakup: a new rapidly changing stress field model. Earth Planet Sci Lett 236:471-485. https://doi.org/10.1016/j. eps1.2005.03.021

Brigaud B, Vincent B, Carpentier C, Robin C, Guillocheau F, Yven B, Huret E (2014) Growth and demise of the Jurassic carbonate platform in the intracratonic Paris Basin (France): Interplay of climate change, eustasy and tectonics. Mar Pet Geol 53:3-29. https://doi.org/10.1016/j.marpetgeo.2013.09.008

Carcel D, Colombié C, Giraud F, Courtinat B (2010) Tectonic and eustatic control on a mixed siliciclastic-carbonate platform 
during the Late Oxfordian-Kimmeridgian (La Rochelle platform, western France). Sediment Geol 223:334-359

Carmignani L, Oggiano G, Funedda A, Conti P, Pasci S, Barca S (2008) Carta Geologica della Sardegna, Scala 1:250.000. Litografia artistica Cartografia, Firenze

Casellato CE, Jadoul F, Lanfranchi A (2012) Calcareous nannofossil biostratigraphy of the S'Adde Limestone (Mt. Albo, Orosei Gulf): insights into the Middle-Late Jurassic eastern Sardinia passive margin evolution. Riv Ital Paleontol Stratigr 118:439-460

Cecca F, Martin Garin B, Marchand D, Lathuiliere B, Bartolini A (2005) Paleoclimatic control of biogeographic and sedimentary events in Tethyan and peri-Tethyan areas during the Oxfordian (Late Jurassic). Palaeogeogr Palaeoclimatol Palaeoecol 222:10-32. https://doi.org/10.1016/j.palaeo.2005.03.009

Cherchi A, Schroeder R (1985) Mesozoic of northwestern Sardinia. In: Cherchi A (ed) 19th European Micropaleontological Colloquium. Micropaleontological researches in Sardinia. Guidebook. pp. $44-56$

Cherchi A, Simone L, Schroeder R (2010) I sistemi carbonatici giurassici della Sardegna orientale (Golfo di Orosei) ed eventi deposizionali nel sistema carbonatico giurassico-cretacico della Nurra (Sardegna nord-occidentale). Parte seconda, i sistemi carbonatici giurassico-cretacei della Nurra. Geological Field Trips 2:122

Colombié C, Carcel D, Lécuyer C, Ruffel A, Schnyder J (2018) Temperature and cyclone frequency in Kimmeridgian greenhouse period (late Jurassic). Glob Planet Change 170:126-145

Costamagna LG (2016) Middle Jurassic continental to marine transition in an extensional tectonics context: the Genna Selole Fm. depositional system in the Tacchi area (central Sardinia, Italy). Geol J 51:722-736

Costamagna LG, Barca S (2004) Stratigraphy, facies analysis, paleogeography and regional framework of the Jurassic succession of the "Tacchi" area (Middle-Eastern Sardinia). Boll della Soc Geol Ital 123:477-495

Costamagna LG, Barca S, Lecca L (2007) The Bajocian-Kimmeridgian Jurassic sedimentary cycle of eastern Sardinia: Stratigraphic, depositional and sequence interpretation of the new 'Baunei Group.' C R Geosci 339:601-612. https://doi.org/10.1016/j. crte.2007.07.010

Crescenti U (1969) Biostratigrafia delle facies mesozoiche dell'Appennino centrale. Geol Romana 8:15-40

Crevello PD, Harris PM (1984) Depositional models for Jurassic reefal buildups. Gulf Coast Sect SEPM Found third Annu Res Conf Proc 57-102

Della Porta G, Kenter JAM, Bahamonde JR (2004) Depositional facies and stratal geometry of an Upper Carboniferous prograding and aggrading high-relief carbonate platform (Cantabrian Mountains, N Spain). Sedimentology 51:267-295. https://doi.org/10.104 6/j.1365-3091.2003.00621.x

Della Porta G, Merino-Tomé O, Kenter JAM, Verwer K (2013) Lower Jurassic microbial and skeletal carbonate factories and platform geometry (Djebel Bou Dahar, High Atlas, Morocco). In: Verwer K, Playton TE, Harris PM (eds) Deposits, Architecture and Controls of Carbonate Margin, Slope and Basinal Settings. SEPM Spec Publ 105:237-263. https://doi.org/10.2110/sepmsp.105.01

Dera G, Brigaud B, Monna F, Laffont R, Pucéat E, Deconinck J-F, Pellenard P, Joachimsk MM, Durlet C (2011) Climatic ups and downs in a disturbed Jurassic world. Geology 39:215-218. https ://doi.org/10.1130/G31579.1

Dera G, Prunier J, Smith PL, Haggart JW, Popov E, Guzhov A, Rogov M, Delsate D, Thies D, Cuny G, Pucéat E, Charbonnier G, Bayon G (2015) Nd isotope constraints on ocean circulation, paleoclimate, and continental drainage during the Jurassic breakup of Pangea. Gondwana Res 27:1599-1615. https://doi.org/10.1016/j. gr.2014.02.006
Dercourt J, Gaetani M, Vrielynck B, Barrier E, Biju-Duval B, Brunet MF, Cadet JP, Crasquin S, Sandulescu M (2000) Atlas PeriTethys, Palaeogeographical Maps. 24 maps and explanatory notes. CCGM/CGMW, Paris, pp 1-269

Dickson JAD (1966) Carbonate identification and genesis as revealed by staining. J Sediment Res 36(2):491-505

Dieni I, Massari F (1985) Mesozoic of eastern Sardinia. In: Cherchi A (ed)19th European Micropaleontological Colloquium. Micropaleontological researches in Sardinia. Guidebook. pp 66-77

Dragičević I, Velić I (2002) The Northeastern margin of the adriatic carbonate platform. Geol Croat 55:185-232

Dromart G, Garcia JP, Picard S, Atrops F, Lécuyer C, Sheppard SMF (2003) Ice age at the Middle-Late Jurassic transition? Earth Planet Sci Lett 213:205-220. https://doi.org/10.1016/S0012 $-821 \mathrm{X}(03) 00287-5$

Dupraz C, Strasser A (1999) Microbialites and microencrusters in shallow coral bioherms (Middle to Late Oxfordian, Swiss Jura Mountains). Facies. https://doi.org/10.1007/bf02537471

Dupraz C, Strasser A (2002) Nutritional modes in coral-Microbialite reefs (Jurassic, Oxfordian, Switzerland): evolution of trophic structure as a response to environmental change. Palaios 17:449471. https://doi.org/10.1669/0883-1351(2002)017\%3c044 9:nmicmr\%3e2.0.co;2

Elliot GF (1956) Further records of fossil calcareous algae from the Middle East. Micropaleontology 2:327-334

El-Sorogy A, Al-Kahtany K, Almadani S, Tawfik M (2018) Depositional architecture and sequence stratigraphy of the Upper Jurassic Hanifa Formation, central Saudi Arabia. J African Earth Sci 139:367-378. https://doi.org/10.1016/j.jafrearsci.2017.12.025

Fallatah MI, Kerans C (2018) Stratigraphic evolution of the Late Jurassic Hanifa formation along the Tuwaiq Escarpment, Saudi Arabia: evidence for a carbonate ramp system. Sediment Geol 363:152-180. https://doi.org/10.1016/j.sedgeo.2017.10.008

Flügel E (2004) Microfacies of carbonate rocks_-analysis, interpretation and application. Springer, Berlin, p 984

Fourcade E, Azema J, Cecca F, Dercourt J, Vrielynck B, Bellio Y, Sandulescu M, Ricou, LE (1993) Late Tithonian palaeoenvironments. In: Dercourt, J, Ricou, LM, Vrienlynck, B (eds) Atlas Téthys Palaeoenvironmental Maps and Explanatory Notes, CGMW, pp 113-134

Franţescu OD (2011) Brachyuran decapods (including five new species and one new genus) from Jurassic (Oxfordian-Kimmeridgian) coral reef limestones from Dobrogea, Romania. N Jb Geol Paläont Abh 259:271-297. https://doi. org/10.1127/0077-7749/2010/0110

Frizon de Lamotte D, Fourdan B, Leleu S, Leparmentier F, de Clarens $P$ (2015) Style of rifting and the stages of Pangea breakup. Tectonics 34:1009-1029. https://doi.org/10.1002/2014TC003760

Gaillard C (1983) Les biohermes à spongiaires et leur environment dans l'Oxfordian du Jura meridional. Doc Lab Géol Lyon 90:515

Golonka J (2004) Plate tectonic evolution of the southern margin of Eurasia in the Mesozoic and Cenozoic. Tectonophysics 381:235273. https://doi.org/10.1016/j.tecto.2002.06.004

Golonka J (2007) Late Triassic and Early Jurassic palaeogeography of the world. Palaeogeogr Palaeoclimatol Palaeoecol 244:297-307. https://doi.org/10.1016/j.palaeo.2006.06.041

Hallam A (1985) A review of Mesozoic climates. J Geol Soc London 142:433-445. https://doi.org/10.1144/gsjgs.142.3.0433

Hallam A (2001) A review of the broad pattern of Jurassic sea-level changes and their possible causes in the light of current knowledge. Palaeogeogr Palaeoclimatol Palaeoecol 167:23-37. https ://doi.org/10.1016/S0031-0182(00)00229-7

Haq BU (2018) Jurassic sea-level variations: a reappraisal. GSA Today 28:4-10. https://doi.org/10.1130/GSATG359A.1 
Haq BU, Hardenbol J, Vail PR (1987) Chronology of fluctuating sea levels since the Triassic. Science 235:1156-1167. https://doi. org/10.1126/science.235.4793.1156

Hardenbol J, Thierry J, Farley MB, Jacquin T, De Gracianky P-C, Vail PR (1998) Mesozoic and Cenozoic sequence chronostratigraphic framework of European basins. In: De Graciansky P-C, Hardenbol J, Jacquin T, Vail PR (eds) Mesozoic and Cenozoic Sequence Stratigraphy of European Basins, SEPM Spec Publ 60:13

Hiatt EE, Pufahl PK (2014) Cathodoluminescence petrography of carbonate rocks: application to understanding diagenesis, reservoir quality, and pore system evolution. Miner Assoc Can Short Course 45:75-96

Hughes GW (2004) Middle to late Jurassic biofacies of Saudi Arabia. Riv Ital Paleontol Stratigr 110:173-179

Hughes GW, Varol O, Al-Khalid M (2008) Late Oxfordian micropalaeontology, nannopalaeontology and palaeoenvironments of Saudi Arabia. GeoArabia 13:15-30

Jadoul F (2018) Stratigraphic-paleogeographic evolution of Eastern Sardinia Jurassic passive margin carbonates: synthesis and future developments. J Mediterr Earth Sci 10:147-154. https://doi. org/10.3304/JMES.2018.006

Jadoul F, Lanfranchi A, Berra F (2009) Evolution of late Jurassic to Berriasian carbonate platforms of Eastern Sardinia. In: Pascucci V, Andreucci S (eds), Field Trip Guide Book, Pre-Conference Field Trip FT3, 27th IAS Meeting of Sedimentology, Alghero, September 20-23, Sassari, pp. 51-71

Jadoul F, Lanfranchi A, Berra F, Erba E, Casellato CE (2010) I sistemi carbonatici giurassici della Sardegna orientale (Golfo di Orosei) ed eventi deposizionali nel sistema carbonatico giurassico-cretacico della Nurra (Sardegna nord-occidentale). Geol Field Trips 2:122. https://doi.org/10.3301/GFT.2010.02

Jansa LF, Pratt BR, Dromart G (1988) Deep water thrombolite mounds from the Upper Jurassic of offshore Nova Scotia. In: Geldsetzer HHJ, James NP, Tebbutt GE (eds) Reefs, Canada and Adjacent Area, Canadian Society of Petroleum Geologists Memoir 13. pp. $725-735$

Jenkyns HC, Schouten-Huibers L, Schouten S, Sinninghe Damsté JS (2011) Middle Jurassic-Early Cretaceous high-latitude sea-surface temperatures from the Southern Ocean. Clim Past Discuss 7:1339-1361. https://doi.org/10.5194/cpd-7-1339-2011

Kiani Harchegani F, Morsilli M (2019) Internal waves as controlling factor in the development of stromatoporoid-rich facies of the Apulia Platform margin (Upper Jurassic-Lower Cretaceous, Gargano Promontory, Italy). Sediment Geol 380:1-20. https://doi. org/10.1016/j.sedgeo.2018.11.011

Kiessling W (2009) Geologic and biologic controls on the evolution of reefs. Annu Rev Ecol Evol Syst 40:173-192. https://doi. org/10.1146/annurev.ecolsys.110308.120251

Lanfranchi A, Berra F, Jadoul F (2011) Compositional changes in sigmoidal carbonate clinoforms (Late Tithonian, eastern Sardinia, Italy): Insights from quantitative microfacies analyses. Sedimentology 58:2039-2060. https://doi.org/10.111 1/j.1365-3091.2011.01250.x

Lathuilière B, Gaillard C, Habrant N, Bodeur Y, Boullier A, Enay R, Hanzo M, Marchand D, Thierry J, Werner W (2005) Coral zonation of an Oxfordian reef tract in the northern French Jura. Facies 50(3-4):545-559. https://doi.org/10.1007/s10347-004-0035-4

Leinfelder RR (1992) A modern-type Kimmeridgian reef (Ota Limestone, Portugal): implications for Jurassic reef models. Facies 26:11-34. https://doi.org/10.1007/BF02539791

Leinfelder RR (1993a) A sequence stratigraphic approach to the Upper Jurassic mixed carbonate-siliciclastic succession of the central Lusitanian Basin, Portugal. Profil 5:119-140

Leinfelder RR (1993b) Upper Jurassic reef types and controlling factors-a preliminary report. Profil 5:119-140
Leinfelder RR, Schmid DU, Nose M, Werner W (2002) Jurassic reef patterns-the expression of a changing globe. In: Kiessling W, Flügel E, Golonka J (eds) Phanerozoic reef patterns, SEPM Special Publication, vol 72, Tulsa. pp. 465-520

Leinfelder RR, Schlagintweit F, Werner W, Ebli O, Nose M, Schmid DU, Hughes GW (2005) Significance of stromatoporoids in Jurassic reefs and carbonate platforms-concepts and implications. Facies 51:287-325. https://doi.org/10.1007/s10347-005-0055-8

Leleu S, Hartley AJ, Van OC, Kennan L, Ruckwied K, Gerdes K (2016) Structural, stratigraphic and sedimentological characterisation of a wide rift system: the Triassic rift system of the Central Atlantic Domain. Earth Sci Rev 158:89-124. https://doi.org/10.1016/j. earscirev.2016.03.008

Martin-Garin B, Lathuilière B, Geister J, Chellai H, Huault V (2007) Geology, facies model and corals association of the Late Jurassic reef complex at Cape Ghir (Atlantic High Atlas, Morocco). CR Geosci 339:65-79

Martin-Garin B, Lathuilière B, Geister J, Ramseyer K (2010) Oxygen isotopes and climatic control of Oxfordian coral reefs (Jurassic, Tethys). Palaios 25:721-729

Martin-Garin B, Lathuilière B, Geister J (2012) The shifting biogeography of reef corals during the Oxfordian (Late Jurassic). A climatic control? Palaeogeogr Palaeoclimatol Palaeoecol 365366:136-153. https://doi.org/10.1016/j.palaeo.2012.09.022

Masini E, Manatschal G, Geoffroy M (2013) The Alpine Tethys rifted margins: reconciling old and new ideas to understand the stratigraphic architecture of magma-poor rifted margins. Sedimentology 60:174-196. https://doi.org/10.1111/sed.12017

Matyszkiewicz J, Kochman A, Du A (2012) Influence of local sedimentary conditions on development of microbialites in the Oxfordian carbonate buildups from the southern part of the Kraków-Częstochowa Upland (South Poland). Sediment Geol 264:109-132. https://doi.org/10.1016/j.sedgeo.2011.08.005

Merino-Tomé Ó, Della Porta G, Kenter JAM, Verwer K, Harris PM, Adams EW, Playton T, Corrochano D (2012) Sequence development in an isolated carbonate platform (Lower Jurassic, Djebel Bou Dahar, High Atlas, Morocco): influence of tectonics, eustacy and carbonate production. Sedimentology 59:118-155. https:// doi.org/10.1111/j.1365-3091.2011.01232.x

Miller KG, Kominz MA, Browning JV, Wright JD, Mountain GS, Katz ME, Sugarman PJ, Cramer BS, Christie-Blick N, Pekar SF (2005) The Phanerozoic record of global sea-level change. Science 310:1293-1298. https://doi.org/10.1126/science.1116412

Molina JM, Reolid M, Mattioli E (2018) Thin-shelled bivalve buildup of the lower Bajocian, South Iberian paleomargin: development of opportunists after oceanic perturbations. Facies $64: 1-17$. https ://doi.org/10.1007/s10347-018-0532-5

Müller DR, Seton M, Zahirovic S, Williams SE, Matthews KJ, Wright NM, Shepard GE, Maloney KT, Barnett-Moore N, Hosseinpour M, Bower DJ, Cannon J (2016) Ocean basin evolution and global-scale plate reorganization events since Pangea breakup. Annu Rev Earth Planet Sci 44:107-138. https://doi.org/10.1146/ annurev-earth-060115-012211

Muttoni G, Visconti A, Channell JET, Casellato CE, Maron M, Jadoul F (2018) An expanded Tethyan Kimmeridgian magnetobiostratigraphy from the S'Adde section (Sardinia): implications for the Jurassic timescale. Palaeogeogr Palaeoclimatol Palaeoecol 503:90-101. https://doi.org/10.1016/j.palaeo.2018.04.019

Nose M (1995) Comparative facies analysis and palaeoecology of coral-bearing shallowing-upwards successions from the Upper Jurassic of Iberia. Profil 8:1-237

Nose M, Leinfelder RR (1997) Upper Jurassic coral communities within siliciclastic settings (Lusitanian Basin, Portugal): implications for symbiotic and nutrient strategies. In: 8th 
International Coral Reef Symposium, Panamá City, Proceedings. pp 1755-1760

Olivier N (2019) Distribution of coral-microbialite reefs along the French Jura platform during the Bimammatum Zone (Oxfordian, Late Jurassic). Bull Geosci 94:257-277

Olivier N, Hantzpergue P, Gaillard C, Pittet B, Leinfelder RR, Schmid DU, Werner W (2003) Microbialite morphology, structure and growth: a model of the Upper Jurassic reefs of the Chay Peninsula (Western France). Palaeogeogr Palaeoclimatol Palaeoecol 193:383-404. https://doi.org/10.1016/S0031-0182(03)00236-0

Olivier N, Pittet B, Mattioli E (2004) Palaeoenvironmental control on sponge-microbialite reefs and contemporaneous deep-shelf marl-limestone deposition (Late Oxfordian, southern Germany). Palaeogeogr Palaeoclimatol Palaeoecol 212:233-263. https://doi. org/10.1016/j.palaeo.2004.06.003

Olivier N, Pittet B, Werner W, Hantzpergue P, Gaillard C (2008) Facies distribution and coral-microbialite reef development on a lowenergy carbonate ramp (Chay Peninsula, Kimmeridgian, western France). Sediment Geol 205:14-33. https://doi.org/10.1016/j. sedgeo.2007.12.011

Olivier N, Colombié C, Pittet B, Lathuilière B (2011) Microbial carbonates and corals on the marginal French Jura platform (Late Oxfordian, Molinges section). Facies 57:469-492. https://doi. org/10.1007/s10347-010-0246-9

Olivier N, Martin-Garin B, Colombié C, Cornée J-J, Giraud F, Schnyder J, Kabbachi B, Ezaidi K (2012) Ecological succession evidence in an Upper Jurassic coral reef system (Izwarn section, High Atlas, Morocco). Geobios 45:555-572

Olóriz F, Reolid M, Rodríguez-Tovar FJ (2003a) A Late Jurassic carbonate ramp colonized by sponges and benthic microbial communities (External Prebetic, Southern Spain). Palaios 18:528-545

Olóriz F, Reolid M, Rodríguez-Tovar FJ (2003b) Palaeogeographic and stratigraphic distribution of mid-late Oxfordian foraminiferal assemblages in the Prebetic Zone (Betic Cordillera, Southern Spain). Geobios 36:733-747. https://doi.org/10.1016/j.geobi os.2003.03.006

Olóriz F, Reolid M, Rodríguez-Tovar FJ (2006) Approaching trophic structure in Late Jurassic neritic shelves: a western Tethys example from southern Iberia. Earth Sci Rev 79:101-139. https://doi. org/10.1016/j.earscirev.2006.06.005

Olóriz F, Reolid M, Rodríguez-Tovar FJ (2012) Palaeogeography and relative sea-level history forcing eco-sedimentary contexts in Late Jurassic epicontinental shelves (Prebetic Zone, Betic Cordillera): an ecostratigraphic approach. Earth Sci Rev 111:154-178. https://doi.org/10.1016/j.earscirev.2011.11.004

Ourribane M, Chellai H, Zaghbib-Turki D (2000) Rôle des microbialites et des "micro-encroûtants" dans la lithification récifale: exemples du Jurassique supérieur de l'Atlas maghrébin (Maroc et Tunisie). C R Acad Sci Paris Sci Planetes 330:407-414

Picotti V, Cobianchi M (2017) Jurassic stratigraphy of the Belluno Basin and Friuli Platform: a perspective on far-field compression in the Adria passive margin. Swiss J Geosci 110:833-850. https ://doi.org/10.1007/s00015-017-0280-5

Pittet B, Mattioli E (2002) The carbonate signal and calcareous nannofossil distribution in an Upper Jurassic section (BalingenTieringen, Late Oxfordian, southern Germany). Palaeogeogr Palaeoclimatol Palaeoecol 179:71-96

Pomar L, Aurell M, Beatriz B, Morsilli M, Fahd A-A (2015) Depositional model for a prograding oolitic wedge, Upper Jurassic, Iberian basin. Mar Pet Geol 67:556-582. https://doi.org/10.1016/j. marpetgeo.2015.05.025

Pratt BR, Jansa LF (1988) Upper Jurassic shallow-water reefs of offshore Nova Scotia. In: Geldsetzer HHJ, James NP, Tebbutt GE (eds) Reefs, Canada and Adjacent Area, Canadian Society of Petroleum Geologists Memoir 13. pp. 741-747
Radoičić R (1959) Nekoliko problematicnih mikrofosila iz dinarske krede (some problematic microfossils from the Dinarian Cretaceous). Vesnik 17:87-92

Reolid M, Gaillard C, Olóriz F, Rodríguez-Tovar FJ (2005) Microbial encrustations from the Middle Oxfordian-earliest Kimmeridgian lithofacies in the Prebetic Zone (Betic Cordillera, southern Spain): characterization, distribution and controlling factors. Facies 50:529-543. https://doi.org/10.1007/s10347-004-0030-9

Reolid M, Gaillard C, Lathuilière B (2007) Microfacies, microtaphonomic traits and foraminiferal assemblages from Upper Jurassic oolitic-coral limestones: stratigraphic fluctuations in a shallowing-upward sequence (French Jura, Middle Oxfordian). Facies 53:553-574. https://doi.org/10.1007/s10347-007-0121-5

Ricci C, Rusciadelli G, Della Porta G, Lanfranchi A, Jadoul F, Lathuilière B (2018) Sedimentary evolution of a coral- microbialites- and debris-rich Upper Jurassic reef (upper Tithonian, eastern Sardinia, Italy). Sediment Geol 376:113-135. https://doi. org/10.1016/j.sedgeo.2018.07.010

Rusciadelli G, Ricci C, Lathuilière B (2011) The Ellipsactinia Limestones of the Marsica area (Central Apennines): a reference zonation model for Upper Jurassic Intra-Tethys reef complexes. Sediment Geol 233:69-87. https://doi.org/10.1016/j.sedge o.2010.10.011

Russo A, Morsilli M (2007) New insight on architecture and microstructure of Ellipsactinia and Sphaeractinia (Demosponges) from the Gargano promontory (southern Italy). Geol Rom 40:215-225

Samankassou E, Strasser A, Di Gioia E, Rauber G, Dupraz C (2003) High-resolution record of lateral facies variations on a shallow carbonate platform (Upper Oxfordian, Swiss Jura Mountains). Eclogae Geol Helv 96:425-440

San Miguel G, Aurell M, Bádenas B, Martinez V, Caline B, PabianGoyheneche C, Rolando JP, Grasseau N (2013) Facies heterogeneity of a Kimmeridgian carbonate ramp (Jabaloyas, eastern Spain): a combined outcrop and 3D geomodelling analysis. J Iber Geol 39:233-252

San Miguel G, Aurell M, Bádenas B (2017) Occurrence of high-diversity metazoan to microbial-dominated bioconstructions in a shallow Kimmeridgian carbonate ramp (Jabaloyas, Spain). Facies 63:1-21. https://doi.org/10.1007/s10347-017-0493-0

Santantonio M, Scrocca D, Lipparini L (2013) The Ombrina-Rospo Plateau (Apulian Platform): evolution of a carbonate platform and its margins during the Jurassic and Cretaceous. Mar Pet Geol 42:4-29. https://doi.org/10.1016/j.marpetgeo.2012.11.008

Schlagintweit F, Gawlick HJ (2007) Analysis of Late Jurassic to Early Cretaceous algal debris-facies of the Plassen carbonate platform in the Northern Calcareous Alps (Germany, Austria) and in the Kurbnesh area of the Mirdita zone (Albania): a tool to reconstruct tectonics and palaeogeography of eroded platforms. Facies 53:209-227. https://doi.org/10.1007/s10347-006-0100-2

Schlagintweit F, Gawlick HJ (2008) The occurrence and role of microencruster frameworks in Late Jurassic to Early Cretaceous platform margin deposits of the Northern Calcareous Alps (Austria). Facies 54:207-231. https://doi.org/10.1007/s10347-007-0131-3

Schlagintweit F, Bover-Arnal T, Salas R (2010) New insights into Lithocodium aggregatum Elliott 1956 and Bacinella irregularis Radoičić 1959 (Late Jurassic-Lower Cretaceous): two ulvophycean green algae (?Order Ulotrichales) with a heteromorphic life cycle (epilithic/euendolithic). Facies 56(4):509-547

Sellwood BW, Valdes PJ (2008) Jurassic climates. Proc Geol Assoc 119:5-17. https://doi.org/10.1016/S0016-7878(59)80068-7

Senowbari-Daryan B, Bucur II, Schlagintweit F, Sasaran E, Matyszkiewicz J (2008) Crescentiella, a new name for "Tubiphytes" morronensis CRESCENTI, 1969: an enigmatic Jurassic-Cretaceous microfossil. Geol Croat 61:185-214. https://doi.org/10.4154/ GC. 2008.17 
Sequero C, Aurell M, Bádenas B (2019) Sedimentary evolution of a shallow carbonate ramp (Kimmeridgian, NE Spain): unravelling controlling factors for facies heterogeneities at reservoir scale. Mar Pet Geol 109:145-174. https://doi.org/10.1016/j.marpe tgeo.2019.06.018

Stampfli GM, Borel GD (2002) A plate tectonic model for the Paleozoic and Mesozoic constrained by dynamic plate boundaries and restored synthetic oceanic isochrons. Earth Planet Sci Lett 196:17-33

Strasser A (1986) Ooids in Purbeck limestones (lowermost Cretaceous) of the Swiss and French Jura. Sedimentology 33:711-727

Strasser A, Védrine S (2009) Controls on facies mosaics of carbonate platforms: a case study from the Oxfordian of the Swiss Jura. In: Swart P, Eberli G, McKenzie J, Jarvis I, Stevens T (eds) Perspectives in carbonate geology: Special Publications International Association of Sedimentologists 41:199-213

Taylor PD, Palmer TJ (1994) Submarine caves in a Jurassic reef (La Rochelle, France) and the evolution of cave biotas. Sci Nat 81(8):357-360

Tišljar J, Velić I (1991) Carbonate facies and depositional environments of the Jurassic and Lower Cretaceous of the coastal Dinarides (Croatia). Geol Vjesn 44:215-234
Trammer J (1989) Middle-to-Upper Oxfordian sponges of the Polish Jura. Acta Geol Pol 39:49-91

Turnšek D, Buser S, Ogorolec B (1981) An Upper Jurassic reef complex from Slovenia, Yugoslavia. In: Tomey DF (ed) European Fossils Reefs Models, SEPM Special Publication 30. pp. 361-369

Vardabasso S (1959) Il Mesozoico epicontinentale della Sardegna. Rend Sci Fis Mat Nat 27:178-184

Velić I, Tišljar J, Vlahović I, Velić J, Koch G, Matičec D (2002) Palaeogeographic variability and depositional environments of the Upper Jurassic Carbonate Rocks of Velika Kapela Mt. (Gorski Kotar Area, Adriatic Carbonate Platform, Croatia). Geol Croat 55:121-138

Vlahović I, Tišljar J, Velić I, Matičec D (2002) The Karst Dinarides are composed of relics of a single Mesozoic platform: facts and consequences. Geol Croat 55:171-184

Weissert H, Mohr H (1996) Late Jurassic climate and its impact on carbon cycling. Palaeogeogr Palaeoclimatol Palaeoecol 122:27-43. https://doi.org/10.1016/0031-0182(95)00088-7 